\title{
1 Investigating the impacts of biochar on water fluxes in 2 tropical agriculture using stable isotopes
}

3 Benjamin M. C. Fischer ${ }^{1,2,3}$, Laura Morillas ${ }^{4}$, Johanna Rojas Conejo ${ }^{5}$, Ricardo Sánchez-Murillo ${ }^{6}$,

4 Andrea Suárez Serrano ${ }^{5}$, Jay Frentress ${ }^{7,8}$, Chih-Hsin Cheng ${ }^{9}$, Monica Garcia ${ }^{10}$, Stefano Manzoni ${ }^{1,3}$,

5 Mark S. Johnson ${ }^{11,12}$, and Steve W. Lyon ${ }^{1,3,13}$

6 [1] Department of Physical Geography, Stockholm University, Stockholm, Sweden.

7 [2] Department of Earth Sciences, Uppsala University, Uppsala, Sweden

8 [3] Bolin Centre for Climate Research, Stockholm University, Stockholm, Sweden

9 [4] Centre for Sustainable Food Systems, The University of British Columbia, Vancouver, British Columbia V6T 1Z4, Canada

[5] Water Resources Center for Central America and the Caribbean (HIDROCEC-UNA), Universidad Nacional de Costa Rica, Guanacaste,

[6] Stable Isotopes Research Group and Water Resources Management Laboratory, Universidad Nacional, Heredia, Costa Rica

[7] Free University of Bolzano, Italy

[8] Water Resources, Ramboll Sverige AB, Stockholm, Sweden

17 [9] School of Forestry and Resource Conservation, National Taiwan University, Taipei, Taiwan

18 [10] Department of Environmental Engineering, Technical University of Denmark, 2800 Kgs. 19 Lyngby, Denmark

[11] Department of Earth, Ocean and Atmospheric Sciences, The University of British Columbia, Vancouver, British Columbia V6T 1Z4 Canada

[12] Institute for Resources, Environment and Sustainability, The University of British Columbia, Vancouver, British Columbia V6T 1Z4, Canada

[13] School of Environment and Natural Resources, Ohio State University, Ohio, USA

25 Correspondence to: B. M. C. Fischer (benjamin.fischer@natgeo.su.se) 


\section{Abstract}

29 Amending soils with biochar, a pyrolyzed organic material, is an emerging practice to potentially

30 increase plant available water. However, it is not clear (1) to what extent biochar amendments increase

31 soil water storage relative to non-amended soils and (2) whether plants grown in biochar amended soils

32 access different pools of water compared to those grown in non-amended soils. To investigate these questions, we set up an upland rice field experiment in a tropical seasonally dry region in Costa Rica, with plots treated with two different biochar amendments and control plots, from where we collected hydrometric and isotopic data $\left(\delta^{18} \mathrm{O}\right.$ and $\delta^{2} \mathrm{H}$ from rain, soil, groundwater and rice plants). Our results show that the soil water retention curves for biochar treated soils shifted, indicating that rice plants had $2 \%$ to $7 \%$ more water available throughout the growing season relative to the control plots. In addition, we observed a within treatment variability in the soil water retention curves which was in the same order of magnitude as one would expect from responses due to differences in biochar application rates or due to differences in biochar typologies. The stable water isotope composition of plant water showed that the rice plants across all plots preferentially utilized the more variable soil water from the top 20 $\mathrm{cm}$ of the soil instead of using the deeper and less variable sources of water. Our results indicated that rice plants in biochar amended soils could access larger stores of water more consistently and thus could withstand dry spells of seven extra days relative to rice grown in non-treated soils. Though supplemental irrigation was required to facilitate plant growth during extended dry periods. Therefore, biochar amendments can complement, but not necessarily replace, other water management strategies. 


\section{1. Introduction}

48 Rainfed agriculture provides food for the growing world population (Fraiture et al., 2009; Fraiture and

49 Wichelns, 2010) without over-exploiting groundwater resources (Famiglietti, 2014; Jasechko et al.,

50 2017). However, the spatial and temporal variability of rainfall makes rainfed agriculture vulnerable to droughts (Fischer et al., 2013) and poses a risk for food security (Fraiture and Wichelns, 2010). Extreme weather events such as El Niño-Southern Oscillation (ENSO) influence global precipitation patterns and can bring prolonged dry spells that limit rainfed agriculture production. This is especially true in the tropics, where rainfall regimes are changing and will continue to change (Feng et al., 2013; Giorgi, 2006; Knutson et al., 2006), leading to more frequent long-term droughts (i.e. periods of more than 10 years with limited rainfall; Hidalgo et al., 2019). Climate projections for the Mesoamerican tropics suggest (1) decreases in rainfall during the wet season (May-November) of $10 \%$ to $25 \%$; (2) expansion of the areas affected by mid-summer droughts; and (3) increases in temperature and extreme dry spells

$59-$ all of which result in a net decrease of water availability (Imbach et al., 2018). Such a decrease in

60 water availability could have significant impacts on rainfed agricultural production and food security

61 globally. Therefore, to reduce societal exposure to risk, it becomes necessary to make rainfed agriculture more resilient to current and future climate variability. (Biazin et al., 2012) or flood water (Castelli et al., 2018), plant and soil water conservation measures (Enfors and Gordon, 2007; Makurira et al., 2007; Vico and Brunsell, 2018) or introducing supplementary irrigation (Mutiro et al., 2006). Amending soils with biochar is an emerging practice in agriculture that could be useful for improving resilience to climate variability (Fischer et al., 2018). Biochar is a collective name for organic material (e.g. woody or herbaceous vegetation, crop residues or waste material) that is pyrolyzed in low-tech (Sundberg et al., 2020) or high-tech furnaces (Liu et al., 2016). The result is a charcoal with different material properties (e.g. particle size, pore structure, surface area and hydrophobicity) from the original feedstock. Biochar can be applied on the soil surface

72 or incorporated in the soil where it alters the original soil matrix thereby changing the infiltration 

soil profile. The altered soil physical characteristics increase the soil water holding capacity and more in general the amount of soil water stored at a given soil matric potential (Omondi et al., 2016). However, despite documented positive effects of biochar amendments on agricultural productivity (Kätterer et al., 2019; Novak et al., 2016), also negligible or no effects have also been observed (Fischer et al., 2018; Jeffery et al., 2015, 2017; Nelissen et al., 2015; Reyes-Cabrera et al., 2017). These diverging findings might be due to different biochar typologies (Fischer et al., 2018), but also to the fact that many of the available studies are based on laboratory and pot experiments unable to mimic the variety of processes occurring in agroecosystems at field scale (Agegnehu et al., 2017; Blanco-Canqui, 2017; Zhang et al., 2016).

At the agroecosystem scale, soil water depends not only on the storage characteristics of the soil, but also on variability of vertical fluxes resulting from rainfall and irrigation, evaporation, leakage and runoff (Falkenmark, 1997; Rockström, 1999; Vico and Porporato, 2015). Thus, biochar impacts could manifest themselves across the myriad pathways by which water can move through the soil-plantatmosphere continuum. Stable water isotopes can be a powerful tool to study how biochar additions modify water stores and fluxes in agroecosystems. As part of the water molecule itself, the stable isotopes of the water $\left({ }^{18} \mathrm{O}\right.$ and $\left.{ }^{2} \mathrm{H}\right)$ in combination with hydrometric data, are a proven tool to trace flow pathways of water from rainfall (Fischer et al., 2017b) to evaporation (Benettin et al., 2018; Gonfiantini, 1986), through the (un)saturated zone (Jasechko et al., 2017; Koeniger et al., 2016; Sánchez-Murillo and Birkel, 2016; Saxena, 1987), catchments (Fischer et al., 2017a; Klaus and McDonnell, 2013) and more recently in the soil-plant-atmosphere continuum (Allen et al., 2019; Brooks et al., 2010; Dawson and Ehleringer, 1991; McDonnell, 2014; Penna et al., 2018; Rothfuss and Javaux, 2017; Sprenger et al., 2016).

Root water resembles the isotopic composition from the absorbed soil water from a specific location in the soil profile (Berry et al., 2018), while, xylem water in the plant stem represents the isotopic composition of all the soil profile within the root network (Dawson and Ehleringer, 1991; Penna et al., 2018). To identify which water stores are available to vegetation, various potential water sources -e.g., rain (Fischer et al., 2019; Prechsl et al., 2014), soil water (Sprenger et al., 2015) and groundwater (Beyer 
et al., 2016) are collected and analyzed for their stable isotope composition. The stable isotope composition of the different collected water has allowed researchers to develop new theories whether plants use soil-bound vs. mobile soil water pools (Brooks et al., 2010) or consume water from specific soil layers that change over time (Berry et al., 2018; Beyer et al., 2016; Goldsmith et al., 2012; Koeniger et al., 2016; Muñoz-Villers et al., 2020). Amin et al (2020) compared results from different stable isotopes studies performed in natural catchments and deduced that plants in dry tropical climates consume water from soil layers deeper than $50 \mathrm{~cm}$. Beyond investigating natural ecosystems, stable isotopes offer opportunities to study the sources of water in agroecosystems and quantifying the efficiency of agricultural innovations.

Despite that stable isotopes have been used to a lesser extent in agricultural systems than in natural systems to investigate plant water sources (Penna et al., 2020), there are successful studies done in coffee (Muñoz-Villers et al., 2020), maize, wheat (Stumpp et al., 2009) and rice cultures

113 (Mahindawansha et al., 2018; Shen et al., 2015). In the case of rice, Shen et al. (2015) observed that

114 flooded rice consumed soil water from 0-15 cm deep, while Mahindawansha et al. (2018) found that upland rice in dry conditions mostly consumed soil water from up to $50 \mathrm{~cm}$ deep except during the maturing stage, when plants shifted to use water from the $10-30 \mathrm{~cm}$ soil depth. Based on this evidence, we hypothesized that amending biochar into the top $10-30 \mathrm{~cm}$ of the soil, as it is commonly done, could increase resilience to climate variability of upland rice in the tropics.

Our study seeks to test this hypothesis explicitly in a field experiment with upland rice in soil amended with two different biochar types vs. a control treatment (no biochar) in a tropical seasonally dry region in northwestern Costa Rica. We use a combination of hydrometric and isotopic data $\left(\delta^{18} \mathrm{O}\right.$ and $\delta^{2} \mathrm{H}$ of rain, soil, groundwater and rice plants) to target 1) to what extent do biochar amendments increase the soil water storage relative to non-amended soils during the growing period of rice? and 2) do rice plants grown in biochar amended soils access different pools of water compared to those grown in nonamended soils? 


\section{Study site and experimental design}

\subsection{Study site}

The biochar rice experiment was conducted at the Enrique Jímenez Núñez Experimental Station (EEEJN) from the Instituto Nacional de Innovación y Transferencia en Tecnología Agropecuaria (INTA) near the city of Cañas in the Guanacaste province of Costa Rica (Figure 1a). Soils at the experimental site are loamy vertosols (Table A1) typically more than $2 \mathrm{~m}$ deep (Diogenes Cubero and Maria José Elizondo, 2014). Guanacaste province is part of the Dry Corridor of Central America (Sánchez-Murillo et al., 2020) and characterized by a seasonally dry tropical climate with marked dry and wet seasons and limited temperature variability over a year (Birkel et al., 2017). The annual average temperature at EEEJN-INTA is $27.4{ }^{\circ} \mathrm{C}$. The dry season typically spans from mid-November to April with virtually no rainfall. Wet season precipitation exhibits a bi-modal distribution dominated by the influence of the Intertropical Convergence Zone with peaks occurring in May/June and September/October. The moderate dry period between these two peaks is usually referred to as the midsummer drought (Magaña et al., 1999). The average annual rainfall in the area is approximately 1,547 $\pm 473 \mathrm{~mm} \mathrm{yr}^{-1}$ based on a 100-year observation record from a meteorological station $\sim 10 \mathrm{~km}$ distance of the experimental site (Figure 2a). The annual average actual evapotranspiration is around 1,100 $\mathrm{mm}$ $\mathrm{yr}^{-1}$ (Sánchez-Murillo and Birkel, 2016). In the last century, $70 \%$ of the driest years in this region (i.e., years with less than $1,153 \mathrm{~mm} \mathrm{yr}^{-1}$ of rainfall, which is the $25^{\text {th }}$ percentile of annual rainfall), occurred during warm ENSO years. Based on the Standardized Precipitation Index (SPI; Naresh Kumar et al., 2009), recurrent below average rainfall has been observed in this region since 1960s (Figure 2b) with a significant periodicity of severe $(\mathrm{SPI}<-1.5)$ and sustained droughts of around 10 years (Hidalgo et al., 2019).

\subsection{Experimental design}

For this experiment two types of biochar were tested to represent a more locally-produced biochar and a more industrially-processed biochar, respectively. Biochar 1 (BC1) was made of locally sourced bamboo (Guadua angustifolia) and produced at the Costa Rica Institute of Technology (TEC, Cartago, CR; Table A1). The feedstock consisted of wood pieces up to $30 \mathrm{~cm}$ in length from construction waste, which were pyrolyzed using a pyrolysis furnace under a temperature ranging $450-480{ }^{\circ} \mathrm{C}$. A second 

pelletized into pellets with $7.6 \mathrm{~mm}$ diameter and $20-30 \mathrm{~mm}$ long and pyrolyzed at $600{ }^{\circ} \mathrm{C}$ under a controlled nitrogen-rich atmosphere. Pyrolyzed pellets were crushed and sieved to $\leq 2 \mathrm{~mm}$ prior to field application.

Within the EEEJN-INTA experimental station, an area of approximately $160 \mathrm{~m}^{2}$ was delineated and divided into three sections of $40 \mathrm{~m}^{2}$ each for treatments. The three different treatment sections, one for each biochar type (BC1 and $\mathrm{BC} 2)$ and a control treatment $(\mathrm{C})$ with no biochar added, were subdivided into three plots each to create three independent monitoring replicates of each treatment (Figure $1 \mathrm{~b}$ ). The $\mathrm{BC} 1$ and $\mathrm{C}$ plots were $7 \mathrm{~m}^{2}$ each ( $5 \mathrm{~m}$ long $\mathrm{x} 1.4 \mathrm{~m}$ wide) in area while the $\mathrm{BC} 2$ plots were $3.5 \mathrm{~m}^{2}$ each (2.5 m long x $1.4 \mathrm{~m}$ wide) in area. This difference in areas between biochar treatments was due to a lower amount of $\mathrm{BC} 2$ being available (shortage of feedstock at the biochar supplier) while securing a similar application rate $\left(1 \mathrm{~kg} \mathrm{~m}^{-2}\right)$ across biochar treatments. For the biochar treatments, the $\leq 2 \mathrm{~mm}$ particle size biochar was mechanically worked into the top $20 \mathrm{~cm}$ of the field prior to planting. It should be noted that $\mathrm{BC} 1$ was incorporated into the field about six months earlier than $\mathrm{BC} 2$ due to logistical constraints. $\mathrm{BC} 1$ addition was followed by an irrigated melon crop on the treated plot prior to our rice experiment.

After the treatment sections were prepared, an upland rice variety Palmar 18 (Oryza sativa L.) was sown simultaneously on the three sections on 18 July 2018 indicating the start of the experiment. For sowing, $5 \mathrm{~cm}$ deep longitudinal rills were created in all plots with a spacing of $25 \mathrm{~cm}$. In each rill, rice seeds were sown by hand of about 1 seed $\mathrm{cm}^{-1}$, equivalent to $20 \mathrm{~g} \mathrm{~m}^{-2}$. After sowing, the rills were covered with soil. During the growing season, rice plants were primarily rainfed which is the standard procedure for the predominant upland rice grown in the region. In some cases, where water sources for irrigation are available, sporadic support irrigation is used by local farmers to support crops and avoid wither. Due to prolonged dry spells that occurred during the study period, all experimental plots were irrigated with $7 \mathrm{~L} \mathrm{~m}^{-2}$ on July 22 and August 25 to assist germination and avoid plant drought damage respectively on each date. Following typical regional crop management practices, fertilizer $\left(100 \mathrm{~g} \mathrm{~m}^{-2}\right.$ 
consisting of $10 \% \mathrm{~N}, 30 \% \mathrm{P}, 10 \% \mathrm{~K}$ in combination of $11 \mathrm{ml}$ MEGAFOL ${ }^{\circledR}$ and $11 \mathrm{~g}$ magnesium sulphate) and insecticide/herbicide ( $2 \mathrm{ml}$ Muralla ${ }^{\circledR}$ Delta; $50 \mathrm{ml}$ Garlon and $20 \mathrm{ml}$ bispiribac sodium) were applied to all experimental plots using $2 \mathrm{~L} \mathrm{~m}^{-2}$ irrigation water on each treatment date (August 10, September 6, and November 5) to support plant growth. At monthly intervals, manual weed control was performed in all plots. Harvest took place on 21 November 2018 and indicated the end of the experiment.

\subsection{Instrumentation and sampling}

\subsubsection{Meteorological and hydrometric observations}

A meteorological station (Vaisala WT520; $1.5 \mathrm{~m}$ height) was used to continuously monitor precipitation, wind speed and direction, air temperature, relative humidity and atmospheric pressure at the site during the entire study period (Figure $1 \mathrm{~b}$ and $\mathrm{c}$ ). Each experimental plot was instrumented with one sensor installed at $15 \mathrm{~cm}$ depth to monitor volumetric soil water content, soil electrical conductivity and soil temperature (model GS3, Decagon Devices, Inc., Pullman USA), and one additional sensor at same depth to monitor soil matric potential and soil temperature (model MPS6, Decagon Devices). Both sensors were between rice rows in each plot (Figure 1c). Additionally, soil samples were collected at $15 \mathrm{~cm}$ soil depth from each plot at the beginning of the experiment and after harvest to determine the gravimetric soil moisture content. These data were used to perform a two-point calibration of the volumetric soil water content measurements derived from the sensors at each plot during the entire time series.

Depth of groundwater levels was measured using a groundwater well (groundwater well A) installed between the $\mathrm{BC} 1$ and $\mathrm{C}$ treatment sections (Figure 1b). The well consisted of screened PVC tube instrumented with a sensor to continuously monitor groundwater level, electrical conductivity and water temperature (model CTD, Decagon Devices). Manual water level measurements were also made every other week during the study period to calibrate the continuous sensor data. All sensors were connected to a datalogger (Campbell CR1000 logger and an AM416 Relay Multiplexer) and programmed to record at 30-minute intervals. 


\subsubsection{Water and plant sample collection}

208 Water samples from different pools of water (namely, rainwater, irrigation water, soil water and groundwater) were collected for isotopic analysis. Rainwater was collected using a funnel connected with tubing to a PET bottle (1.5 liter) wrapped in aluminum foil similar to Prechsl et al. (2014). In each plot, lysimeters (Soilmoisture equipment corp., Santa Barbara, USA) were installed in the soil reaching to $15 \mathrm{~cm}$ and $40 \mathrm{~cm}$ soil depth respectively to sample soil water. Groundwater samples were collected from a second groundwater well (groundwater well B) installed near the $\mathrm{BC} 2$ treatment section (Figure $1 b)$.

Rainwater samples were collected daily at 7:00 AM. Water from additional application sources such as irrigation (to supplement rainfall) and fertilizer/pesticide/herbicide applications were sampled as a grab sample using a PE bottle during each application. Soil water and groundwater samples were collected approximately biweekly (every other week) after plant germination from 31 July 2018 until the harvest day on 21 November 2018, resulting in 11 sampling days. Soil water was collected from lysimeters by applying an 800-mbar vacuum for 2 minutes. Groundwater was sampled by purging the well and waiting 1 hour before collecting the groundwater sample. All water samples were collected in $30 \mathrm{ml} \mathrm{PE}$ bottles, which were capped and sealed with Parafilm ${ }^{\circledR}$ for transport and cold storage $\left(5^{\circ} \mathrm{C}\right)$ until analysis. At the end of each sampling day, all excess water from all sampler tubing, bottles, and suction lysimeters was removed to prevent inter-sampling contamination.

Plant material from the rice plants was also collected on each of the 11 biweekly sampling dates at around 12:00 noon. For plant material sampling, six rice plants were randomly selected within each plot. The plant height from the soil to the plant tip was measured and recorded before sampling. To avoid loss of biomass on sampled plants, the plants were extracted using a small knife which was carefully wiggled into the soil. The roots, stems and leaves of the extracted plants were separated immediately and transferred into double re-sealable zipper storage bag. To minimize post-sampling transpiration, storage bags were directly placed in a cooler with ice. All plant material was stored in the laboratory freezer $\left(-80^{\circ} \mathrm{C}\right)$ before extracting the plant water for isotopic analysis. 
233 3. Laboratory methods and data analysis

\subsection{Plant water extraction}

Plant water was extracted from the stem (xylem water) of the different rice plants to infer which sources of water the rice plants used. We used the cryogenic vacuum extraction technique described by Koeniger et al., (2011) to extract the plant water for stable isotope analysis. The method uses a heated vial and a cold trap vial (Exetainer ${ }^{\circledR}$ vial with standard cap and rubber septum, Labco Ltd, Lampeter, United Kingdom) connected with stainless-steel capillary tubing. About $3 \mathrm{~g}$ of plant material from the rice stem was placed in the heated vial before the system was evacuated to $85 \mathrm{kPa}$ with a vacuum hand pump (Mityvac). The heated vial was heated for 1 hour at $100^{\circ} \mathrm{C}$ using a test tube heater (HI839800 COD Test Tube Heater; Hanna instruments) while the cold trap vial rested in a Dewar flask containing liquid nitrogen at about $-196^{\circ} \mathrm{C}$. After the extraction was stopped, the cold trap vial was sealed with Parafilm and left to thaw. After thawing, the extracted liquid water was pipetted into $2 \mathrm{ml}$ vials $(32 \mathrm{x}$ $11.6 \mathrm{~mm}$ screw neck vials with cap and PTFE/silicone/PTFE septa) and stored cold $\left(5^{\circ} \mathrm{C}\right)$ until stable isotope analysis. On average $86 \pm 5 \%$ plant water was extracted from xylem.

\subsection{Isotope analysis}

All non-plant water samples were filtered $(0.45 \mu \mathrm{m}$ filter $13 \mathrm{~mm}$ PTFE Syringe Filter, Fisher scientific) and pipetted in vials $(2 \mathrm{~mL}$ into a $1.5 \mathrm{~mL} 32 \times 11.6 \mathrm{~mm}$ screw neck vials with cap and PTFE/silicone/PTFE septa) prior to analysis. Water stable isotopes analysis was conducted at the Stable Isotopes Research Group facilities of the Universidad Nacional of Costa Rica using a water isotope analyzer LWIA-45P (Los Gatos Research Inc., USA). All data were normalized and corrected for drift and memory effects. The analytical long-term error was $\pm 0.5(\%)(1 \sigma)$ for $\delta^{2} H$ and $\pm 0.1(\%)(1 \sigma)$ for $\delta^{18} \mathrm{O}$

Plant water stable isotopes analysis was conducted at the Swedish University of Agricultural Sciences (SLU) Stable Isotope Laboratory (SSIL) in Umeå using an Isotope Ratio Mass Spectrometer (TC/EAIRMS; DeltaV Advantage, Thermo Fisher Scientific, Bremen, Germany; High Temperature Conversion Elemental Analyzer, Thermo Fisher Scientific, Bremen, Germany and an AI 1310 Autosampler, Thermo Fisher Scientific, Bremen, Germany). All water samples were injected into a glassy carbon 

separated on a column and analyzed on a mass spectrometer. All data were corrected for drift and memory. The analytical precision and accuracy were $\pm 2(\%)(1 \sigma)$ for $\delta^{2} H$ and $\pm 0.15(\%)(1 \sigma)$ for $\delta^{18} \mathrm{O}$.

All stable isotope compositions are presented as delta notations $(\delta)$ in \%o, relating the ratios $(\mathrm{R})$ of ${ }^{18} \mathrm{O} /{ }^{16} \mathrm{O}$ and ${ }^{2} \mathrm{H} /{ }^{1} \mathrm{H}$, relative to the VSMOW-SLAP scale. The Global Meteoric Water Line (GMWL) was defined as $\delta^{2} \mathrm{H}=8 \cdot \delta^{18} \mathrm{O}+10$ by Craig (1961). The Local Meteoric Water Line (LMWL) was derived as $\delta^{2} \mathrm{H}=7.4 \cdot \delta^{18} \mathrm{O}+5.5 \mathrm{using}$ the long term isotopic data from the rain sampler at the Water Resources Center for Central America and the Caribbean (Sánchez-Murillo et al., in review) located $\sim 50 \mathrm{~km}$ distance of the experimental site. In addition, the deuterium excess ( $d$-excess) was defined as $d$-excess $=\delta^{2} \mathrm{H}-8 \cdot \delta^{18} \mathrm{O}($ Dansgaard, 1964).

\subsection{Evapotranspiration and soil water retention impacts}

Daily evapotranspiration rates $(E T)$ from the experimental area were estimated by the crop coefficient method $\left(E T=K_{c} \cdot E T_{r e f}\right)$ or FAO56 Penman-Monteith method (Allen et al., 1998). We used site specific meteorological observations to estimate daily reference $E T\left(E T_{r e f}\right)$ and experimentally derived crop coefficient $\left(K_{c}\right)$ values for the three different stages of the crop growth (initial, mid-season, and lateseason). Instead of using globally averaged values of $K_{c}$ for rice (Allen et al., 1998), we used regionspecific $K_{c}$ values experimentally derived from a nearby field experimental site equipped with an Eddy Covariance (EC) tower where the same variety of upland rice is grown (Morillas et al., 2019). Daily $K_{c}$ values from the EC site where derived as the ratio of daily measured $E T$ and site-specific $E T_{r e f}$, and then averaged for the three stationary crop growth stages $\left(K_{c}\right.$ initial $=0.7, K_{c}$ mid-season $=0.9$ and $K_{c}$ late season $=0.5$ ). The length of each crop growth stage was also calibrated for this region by observing the pattern of daily measured ET over the whole growing season (initial $\approx 25$ days, development $\approx 20$ days, mid-season $\approx 50$ days, late-season $\approx 23$ days for an average growing season of 120 days).

Field derived 30-minute records of all meteorological and hydrometric observations (precipitation, volumetric soil water content, soil matric potential and groundwater level) were aggregated to daily averages. Accumulated precipitation and evapotranspiration were also derived from daily 

were calculated by averaging the observations in the three replicated plots per treatment. soil water retention curves using the Van Genuchten model (Van Genuchten, 1980) (Eq. 1)

$$
\theta=\theta_{r}+\frac{\theta_{s}-\theta_{r}}{\left[1+(\alpha \psi)^{n}\right]^{m}}
$$

where $\theta_{r}[\%], \alpha[-]$ and $n[-]$ represent residual, and the fitted scale and shape parameters, respectively; parameter and $m=1-1 / n[-]$ while saturation soil moisture $\left(\theta_{s}\right)$ is based on field observations. To examine the effect of biochar on soil physical and hydraulic properties, we compared the indicators $\theta_{W P}$; $\theta_{F C}$ and van Genuchten parameter $\alpha$ and $n$ estimated for the biochar amended treatments (BC1 and $\mathrm{BC} 2)$ with the same indicators for the unamended treatment $(\mathrm{C})$ using response ratios $(R R)$ as in Fischer et al. (2018). For this study, $R R$ represents the ratio of the variable of interest in the treatment to the same property in the control such that $R R>1$ or $\mathrm{R}<1$ indicates that the treatment has a positive or respectively negative effect.

\subsection{Plant water source estimation}

The isotopic composition of the water samples was represented in the dual isotope space $\delta^{18} \mathrm{O}$ and $\delta^{2} \mathrm{H}$ to infer which sources of water rice plants consumed. To represent a potential plant water source under rainfed conditions, the isotope composition of rainfall was considered as the volume weighted isotope composition of rainfall collected in the two-week period before a given plant water sampling day. Since residual rainfall can evaporate while in the soil (simplified assumption not accounting of mixing with pre-event water), the isotopic composition of the residual rainfall for each water sampling day was estimated following (Gonfiantini, 1986) and (Benettin et al., 2018)

$$
\delta_{P R}=\left(\delta_{P}-\delta^{*}\right)\left(1-f_{E}\right)^{U}+\delta^{*}
$$

where $\delta_{\mathrm{PR}}[\% 0], \delta_{\mathrm{P}}[\% 0]$, and $f_{E}[-]$ represent the isotopic compositions of the residual rainfall, the volume weighted isotope composition of rainfall collected in the two-week period before a sampling 
310 day, and the fraction of rainfall that fell in the two-week period before a sampling day and that has

311 evaporated on the sampling day, respectively. The variables $\delta^{*}[\%]$ and $U[-]$ represents the limiting

312 isotopic composition and the temporal enrichment slope, which were determined using equation 3 and

3134 respectively

$$
\begin{gathered}
\delta^{*}=\frac{R_{H} \delta_{A}+\varepsilon_{k}+\frac{\varepsilon^{+}}{\alpha^{+}}}{R_{H}-10^{-3}\left(\varepsilon_{k}+\frac{\varepsilon^{+}}{\alpha^{+}}\right)} \\
U=\frac{R_{H}-10^{-3}\left(\varepsilon_{k}+\frac{\varepsilon^{+}}{\alpha^{+}}\right)}{1-R_{H} \varepsilon_{k}}
\end{gathered}
$$

314 where $\mathrm{R}_{\mathrm{H}}[-]$ represents the average relative humidity of the two-week period before a sampling day, $\delta_{\mathrm{A}}$

$315[\%]$ the approximation of the isotopic composition of the atmospheric vapor (equation 5 following

316 Gibson et al., (2016)), $\varepsilon_{\mathrm{k}}[\% \mathrm{o}]$ the simplified kinetic fractionation factor (Eq. 6) and $\varepsilon^{+}[\% \mathrm{o}]$ and $\alpha^{+}[-]$the

317 two equilibrium fractionation factors (Eq. 7 and 8).

$$
\begin{gathered}
\delta_{A}=\frac{\delta_{P}-\varepsilon^{+}}{\alpha^{+}} \\
\varepsilon_{k}=\left(1-R_{H}\right)\left(1-S_{180 \text { or } 2 H}\right) 10^{3} \\
10^{3} \ln \left(\alpha^{+} \delta^{2} H\right) \\
=1158.8 \frac{T^{3}}{10^{9}}-1620.1 \frac{T^{2}}{10^{6}}+794.84 \frac{T}{10^{3}}-161.04 \\
+2.9992 \frac{10^{9}}{T^{3}}
\end{gathered}
$$

or

$$
\begin{gathered}
10^{3} \ln \left(\alpha^{+} \delta^{18} O\right)=0.3504 \frac{10^{9}}{T^{3}}-1.6664 \frac{10^{6}}{T^{2}}+6.7123 \frac{10^{3}}{T}-7.685 \\
\varepsilon^{+}=\left(\alpha^{+}-1\right) 10^{3}
\end{gathered}
$$



temperature of the two-week period before a sampling day. The volume-weighted isotope composition of rainfall before each sampling day, which was generally near the GMWL and LMWL, and the corresponding estimated isotopic composition of the residual rainfall, which was generally off the GMWL and LMWL, provided the start and end point of a theoretical evaporation line in dual isotope space. Similarly, an evaporation line for the median sampled soil water of a period was developed. Such evaporation lines map the evolution of the soil water available from residual rainfall or evaporated soil water for plants to be consumed between sampling days allowing us to track which stores of water the rice plants interact with across the treatments. In addition, the within treatment variability defined as difference between the minimum and maximum observed isotopic composition of plant water within a treatment on any given sampling day were calculated.

\section{Results}

\subsection{Hydrometric variability}

Based on the temporal variability of rainfall, we identified three distinct periods within the overall study period (Figure 3). Period I (18 July to 20 September) was characterized with alternating wet and dry days, Period II (20 September to 9 November) presented consistent high daily rainfall inputs, and Period III (10 November to 21 November) was characterized by a long dry spell ending with rice harvest. Throughout the study period, daytime air temperatures were around $26.7^{\circ} \mathrm{C}\left(\right.$ standard deviation $=3{ }^{\circ} \mathrm{C}$ ) and evapotranspiration rates on average $3.1 \mathrm{~mm} \mathrm{day}^{-1}\left(\right.$ standard deviation $\left.=0.7 \mathrm{~mm} \mathrm{day}^{-1}\right)$.

During Period I (germination and vegetative phase), the rice in the different plots grew to a height of $50 \mathrm{~cm}$ in all experimental plots (standard deviation $<2.5 \mathrm{~cm}$ ). This period was characterized by intermittent dry and wet spells with accumulated precipitation slightly higher than evapotranspiration $\left(\mathrm{P}_{\text {cum }}=240 \mathrm{~mm}\right.$ and $\mathrm{ET}_{\text {cum }}=191 \mathrm{~mm}$ over the 64-day period; Figure $\left.3 \mathrm{~b}\right)$. During this period, the maximum recorded volumetric soil water contents were $40 \%, 43 \%$, and $35 \%$, and decreased to the minimum values $30 \%, 25 \%$, and $23 \%$ in the $\mathrm{BC} 1, \mathrm{BC} 2$, and control treatment, respectively (Figure 3c). Regarding soil matric potential $(\psi)$ during this period, it surpassed field capacity $\left(\psi_{F C}=-0.05\right.$ $\mathrm{MPa}$ ) with a maximum of $-0.008 \mathrm{MPa}$ during rain events and decreased to a minimum of $-0.32 \mathrm{MPa}$ 
observed in all treatments a few days after the third sampling day as a result of the driest spell of Period I (Figure 3d). Generally, the soil matric potential in the biochar treatments was $0.002 \mathrm{MPa}$ higher than in the control treatment and never reached the wilting point $\left(\psi_{W P}=-1.5 \mathrm{MPa}\right)$. The groundwater level was generally $0.7 \mathrm{~m}$ below the surface, rising after sampling day 1 to less than $0.6 \mathrm{~m}$ below the surface before sampling day 4 , and to less than $0.5 \mathrm{~m}$ below the surface in response to the largest rainfall of Period I (Figure 3e).

During Period II (vegetative and reproductive phase), rice plants attained their maximum heights of around $100 \mathrm{~cm}$ (standard deviation $<5 \mathrm{~cm}$ ), across all three plots (Period II was the wettest period with 15 out of 42 rain days with intensities greater than $20 \mathrm{~mm} \mathrm{~d}^{-1}$ of rainfall (and one day with $93 \mathrm{~mm} \mathrm{~d}^{-1}$ ) (Figure 3a and $\mathrm{b}$ ). This wet condition lead to cumulative precipitation being much greater than cumulative evapotranspiration during the period $\left(\mathrm{P}_{\text {cum }}=570 \mathrm{~mm}\right.$ and $\mathrm{ET}_{\text {cum }}=147 \mathrm{~mm}$; over the 50-day period). The volumetric soil water content over Period II was generally higher than in Period I, with multiple peaks driven by rainfall events and then a decrease towards the end of the period. After rain events, the volumetric soil water contents rose from $28 \%$ to $40 \%$, from $24 \%$ to $45 \%$, and from $23 \%$ to $36 \%$ in $\mathrm{BC} 1, \mathrm{BC} 2$, and control treatment, respectively. Soil moisture then decreased in the three treatments to $32 \%, 38 \%$, and $32 \%$ during the last part of the period. The soil matric potential during Period II remained largely above field capacity except by the end of the period when it decreased (before sampling day 8 ) to a minimum of $-0.23 \mathrm{MPa}$ in $\mathrm{BC} 1$ and $-0.16 \mathrm{MPa}$ in $\mathrm{BC} 2$ and $\mathrm{C}$. The groundwater level increased multiple times during this period from $0.7 \mathrm{~m}$ below the surface to reach the soil surface the rainiest day of the study period. Between Sampling days 6 and 7, groundwater level remained no lower than $0.4 \mathrm{~m}$ below the surface.

During the final experimental period, Period III (ripening phase), rice plants maintained their maximum height acquired by the end of Period II. This period was characterized by a 12 day long dry spell such that cumulative evapotranspiration was greater than cumulative precipitation $\left(\mathrm{P}_{\text {cum }}=2 \mathrm{~mm}\right.$ and $\mathrm{ET}_{\text {cum }}=$ $63 \mathrm{~mm}$; 12-day period). By the end of Period III, the volumetric soil water content in the $\mathrm{BC} 1$ and $\mathrm{BC} 2$ treatments converged to the lowest observed value of $\sim 21 \%$. It is relevant that the control treatment reached this value about seven days earlier than the biochar amended plots, and the control plots 
continued decreasing to reach a minimum value of $18 \%$ (Figure $3 \mathrm{c}$ ). The soil matric potential for all three plots decreased from above the field capacity to near the wilting point by the end of Period III. The groundwater level also decreased from $0.4 \mathrm{~m}$ to $0.8 \mathrm{~m}$ below the surface (i.e. the sampling well went dry).

\subsection{Impact of biochar on soil water retention curves}

The soil water retention curves from the different treatments showed different shapes and different volumetric water content at a given soil matric potential (Figure 4). Comparing the different soil water retention curves across the different plots of the different treatments shows a within treatment variability, i.e., range of different volumetric soil moisture contents relative to the observed soil matric potentials (Figure 4). Comparing the different soil water retention curves across the periods shows that biochar treatments increased volumetric soil moisture content relative to the control treatment consistently across the ranges of observed soil matric potentials in all three periods (Figure 4, Table A2). The soil water retention curves estimated for Period III were shifted to lower volumetric water contents relative to the other periods and ranged from close to field capacity to wilting point.

The effect of biochar on the soil water retention curve can also be quantified by the response ratios of the wilting point, field capacity and the van Genuchten parameters $\alpha$ and $n$. Most of these ratios were found to be larger than one (Table 1), which indicates increased soil water content for a given water potential value.

\subsection{Isotopic variability} Overall, the $\delta^{18} \mathrm{O}$ and $d$-excess of rainfall was between $-15.7 \%$ and $-0.2 \%$ o $\left(\mathrm{S}_{\mathrm{D}}=3.4 \%\right.$ ) and $0 \%$ and $+18 \%\left(\mathrm{~S}_{\mathrm{D}}=4.6 \%\right)$ respectively $\left(\delta^{18} \mathrm{O}\right.$ see Figure $5 \mathrm{a}, d$-excess see Figure $\mathrm{A} 2 \mathrm{a}$ and $\left.\mathrm{A} 3\right)$. The $\delta^{18} \mathrm{O}$ and $d$-excess of soil water and groundwater collected on the different sampling days was between $-7.5 \%$ and $-4.5 \%$ ( $\left(\mathrm{S}_{\mathrm{D}}=1.3 \%\right.$ ) and $-1.1 \%$ and $+9.7 \%$ o $\left(\mathrm{S}_{\mathrm{D}}=4.9 \%\right)$ respectively $\left(\delta^{18} \mathrm{O}\right.$ see Figure $5 \mathrm{~b}-\mathrm{d}, d-$ excess see Figure A2b-d and A3). The within treatment variability in isotopic composition of soil water samples for each sample day was $<1 \%$ for $\delta^{18} \mathrm{O}$ and $<6 \%$ for $d$-excess (Figure 6). The $\delta^{18} \mathrm{O}$ and $d$ excess of plant water was between $-8.7 \%$ and $-2.7 \%\left(\mathrm{~S}_{\mathrm{D}}=3.7 \%\right.$ ond $-14.6 \%$ to $+3.2 \%$ o $\left(\mathrm{S}_{\mathrm{D}}=11.4\right.$ \%) respectively $\left(\delta^{18} \mathrm{O}\right.$ see Figure $5 \mathrm{~b}-\mathrm{d}, d$-excess see Figure A2b-d and A3). The within treatment 
variability in isotopic composition of plant water samples on each sample day $>3 \%$ for $\delta^{18} \mathrm{O}$ and $>8 \%$ o for $d$-excess (Figure 6). The within treatment variability was smaller for the biochar amended treatments relative to the within treatment variability in the control treatment (Figure 6).

During Period I, the isotopic composition of rainfall varied between $-5.6 \%$ to $-0.2 \%$ for $\delta^{18} \mathrm{O}$ (Figure 5a) and from $-1.1 \%$ to $+9 \%$ for $d$-excess (Figure A2). On rainy days when rainfall intensities were below $10 \mathrm{~mm} \mathrm{~d}^{-1}$, sub-cloud evaporation may exert an important control on rainfall enrichment (Sánchez-Murillo et al., 2016, 2017) and potentially also the low amount of rain water collected in relation to the bottle volume causing water to evaporated water in the sampler. For example, the observed fractionated isotopic compositions of these rain samples were often recorded to be $<5 \%$ with regard to $d$-excess. The average isotopic composition of plant water in the different treatments decreased from roughly from $+3.2 \%$ to $-4 \%$ for $\delta^{18} \mathrm{O}$ and increased from roughly $-40 \%$ to $+18 \%$ for $d$-excess during Period I (Figures 5 and A2). In Period II, the isotopic composition of rainfall varied between $3.7 \%$ to $-12.7 \%$ for $\delta^{18} \mathrm{O}$ (Figure $5 \mathrm{a}$ ) and $+6 \%$ to $+11.8 \%$ for $d$-excess (Figure A2). The average isotopic composition of plant water varied in all treatments to between $-7 \%$ to $-2 \%$ for $\delta^{18} \mathrm{O}$ and -11.8 $\%$ to $+9.2 \%$ for $d$-excess. It should be noted that there was a change from negative to positive $d$-excess for the plant water isotopic compositions between sampling day five and seven, indicating a change from highly fractionated isotopic compositions to compositions similar to that of rainfall. During the dry spell of Period III no rainfall occurred and hence no rainwater was collected. Also, no soil water could be extracted from lysimeters sampling water from 15 below the surface on sampling day 10 and day 11 . The average isotopic composition of plant water varied between $-7 \%$ to $-6 \%$ for $\delta^{18} \mathrm{O}$ and-7 $\%$ to $-2 \%$ for $d$-excess, showing a high fractionation signature (Figures $5, \mathrm{~A} 2$ and A3).

\subsection{Using dual isotope space to characterize plant water sources}

Rainfall isotopic compositions fell along the GMWL and LMWL for our experimental site (Figure 7).

The soil water and ground water isotopic samples from Period I were more fractionated, i.e. they deviated from the GMWL, compared to soil water isotopic samples from the wet Period II and III which fell more along the GMWL (Figure 8). The plant water isotopic compositions from the different treatments and sampling periods were somewhat different from each other in terms of absolute values 

deviated from the GMWL and moved primarily along the modeled evaporation lines of the sampled soil water (Figure $7 \mathrm{a}, \mathrm{d}$ and $\mathrm{g}$ ). The plant water thus resembled soil water with a strong evaporation signature in Period I.

In Period II, which was much wetter than Period I, the plant water samples fell on or were close to the GMWL independent of the treatment and moved from sampling day to sampling day along the GMWL. It is likely that plant water responded to the replenished soil water that acquired the signature of rainfall during this period. At the end of Period II, plant water samples from $\mathrm{BC} 1$ and the control treatment showed a more fractioned signature and fell on the modelled evaporation line indicating that plant water resembled soil water with signature from evaporated rain from day 8 (Figure $7 \mathrm{~b}$ and h). Plant water samples in the $\mathrm{BC} 2$ treatment, however, showed the signature from soil water more similar to original rainfall (Figure 7 e and e2). During the dry Period III, all plant water samples deviated from the GMWL and fell along modeled evaporation lines with signature of residual rainfall that had fallen in Period II (depicted in blue in Figure $7 \mathrm{c}, \mathrm{f}$, and i).

\section{Discussion}

\subsection{Variable effect of biochar on the soil hydraulic properties}

Incorporating two different types of biochar in plots planted with rice affected the soil hydraulic properties. The soil water retention curves of the biochar amended treatments showed higher soil water contents at similar matric potential relative to the control treatment, leading to more plant water available under similar conditions (Figure 4, Table 1). The soil water retention curve of the $\mathrm{BC} 1$ treatment became more similar to the curves found in finer grained soils, which indicates increased water retention, a common expected impact of biochar additions (Fischer et al., 2018; Sun and Lu, 2014). Conversely, the soil water retention curve for the BC2 treatment became more similar to the curves associated with coarser soils indicating enhanced water flows, which has also been described as a potential impact of biochar additions (Fischer et al., 2018; Liu et al., 2017).

The overall soil response to biochar amendments in our experiment had a within treatment variability but was comparable to the response found in other tropical soils where a lower range of $\theta_{\mathrm{WP}}$ and $\theta_{\mathrm{FC}}$ 

compared to laboratory derived soil water retention curves reported in the literature (Iiyama, 2016; Morgan et al., 2001) which usually present one single continuous drying curve (e.g. Batool et al., 2015; Gląb et al., 2016 or Obia et al., 2016). Instead the field-data derived soil water retention curves in the present study were field derived and the result of temporally variable atmospheric forcing. Specifically, our observed within treatment variability in the soil water retention curves was a same order of magnitude as the responses due to differences in biochar application rates or due to differences in biochar typologies reported in laboratory studies (e.g. Batool et al., 2015; Gląb et al., 2016 or Obia et al., 2016). Laboratory studies may overestimate the volumetric soil moisture content at a given soil matric potential compared to field-derived soil water retention curves (Iiyama, 2016; Morgan et al., 2001).

Although the two biochar types tested were produced in different ways, their experimental application was similar (i.e. same application rate, similar particle size, application amount, depth, site characteristics and climate). One key distinction between the two biochar treatments was the application date, which may be important because aging can change the physical and chemical characteristics of biochar (Blanco-Canqui, 2017). Due to some logistical constraints, biochar was introduced to the BC1 plot about six months before the $\mathrm{BC} 2$ plot. This allowed the biochar to age in situ and for the disturbed soils to settle under the $\mathrm{BC} 1$ treatment. Thus, the $\mathrm{BC} 2$ soil likely had relatively larger macropores that could have increased the connectivity of the $20 \mathrm{~cm}$ soil layer where biochar was applied with deeper soil layers. This difference in application timing may have influenced the hydraulic differences in results observed between the two biochar treatments (Figure 4) and amplified the differences due to the contrasting production methods. Clearly, the interplay of all the possible biochar variables with all the possible site-specific heterogeneities makes it challenging to isolate the biochar effect in agroecosystems. Taken altogether, these differences in biochar treatment responses and the relative impacts of both B1 and B2 biochar treatments compared to the control plot highlights the potential for variability in biochar responses - which has been documented in the literature (Fischer et al., 2018) and creates ambiguity around predicting the response of biochar amendments at field scale. This further 

decisions are made.

\subsection{Temporally variable soil water fluxes}

The isotopic composition of different water samples was useful to infer how water fluxes varied through time. The isotopic composition of soil water sampled at two different depths across the plots was rather stable over time compared to the temporally variable isotopic composition of rainfall (Figure 5). In addition, the temporal variability of isotopic composition of soil water from our experiment was less than the spatial variability or change in isotopic composition with depth reported in previous biochar studies (e.g. Beyer et al., 2016; Koeniger et al., 2016; Saxena, 1987 and Sprenger et al., 2016). When comparing our findings with other tropical systems, the $d$-excess of the soil water we found during dry spells (Figure A2) had a smaller variation range than observed in a coffee plantation in Mexico by Muñoz-Villers et al. (2020) and was generally less variable than observations made by JiménezRodríguez et al. (2020) in a tropical wet forest in Costa Rica. The low $d$-excess values and ranges of the soil water observed in this study indicate high evaporative processes in the top soil layer (Amin et al., 2020; Sprenger et al., 2016). This is consistent with our high estimated evapotranspiration rates (average $3.1 \mathrm{~mm} \mathrm{day}^{-1}$ up to $6 \mathrm{~mm} \mathrm{day}^{-1}$ ) which are typical for the Dry Corridor of Central America characterized by high solar radiation and air temperatures (Morillas et al., 2019).

During Period I, when rice plants were small and sparse, leaving much bare soil, the evaporation occurring from the soil across the different treatments was homogenous, creating a low $d$-excess signal in the soil water. During wet spells in Period II, the $d$-excess increased slightly, indicating mixing of rainfall with soil water. At the end of Period II and throughout Period III, the $d$-excess remained higher despite high evaporation, which might be due to a more homogenous crop cover creating a consistent microclimate as described by Sprenger et al. (2017). The isotopic composition of groundwater (1) had $d$-excess values similar to that of meteoric water during dry spells and (2) decreased during wet spells showing a high evaporative signal (Figure A2). Such observed changes in $d$-excess are generally not found in temperate zones (Sprenger et al., 2016), but indicate that rainfall flushed the fractionated soil water downwards promoting mixing with groundwater (Gat and Airey (2006). 


\subsection{Temporally variable plant water sources}

508 The studied rice plants had different water sources available during different periods of the experiment,

509 but what water did they consume?

510 It is likely that the fractionation observed in the plant water collected in this study represents fractioned soil water that was consumed by the plants. This is consistent with results observed in previous studies

512 using stable water isotopes to map out plant water sources (Brooks et al., 2010; Penna et al., 2020;

513 Sprenger et al., 2016). Further, this interpretation of plant water composition is supported by plant water

514 samples falling along the theoretical evaporation lines estimating how soil water would evolves isotopically due to evaporation. Therefore, it is likely that during Period I, the young rice plants (with shallow root system $<20 \mathrm{~cm}$ as reported by Mahindawansha et al. 2018) consumed the fractionated soil water (Figure 7) which was not sampled with the lysimeters at $15 \mathrm{~cm}$ and $40 \mathrm{~cm}$ below the surface.

During Period II, plants grew to their maximum heights with roots reaching deeper soil layers (length $>60 \mathrm{~cm}$ as reported by Mahindawansha et al. 2018). This means that the rice plants, similar to larger vegetation e.g. trees (Allen et al., 2019), would have had access to deeper and more-stable pools of water with a distinct lower $d$-excess signature. However, the isotopic composition of plant water during this period followed the GMWL (Figure $7 \mathrm{~b}$, e and h), indicating that plants consumed largely shallow soil water from recent rainfall. In Period III, it became increasingly difficult to extract water from lysimeters at $15 \mathrm{~cm}$ below the surface and the isotopic composition of plant water drifted from the GMWL, along the theoretical evaporation line of residual rainfall which fell in Period II. With the experiment being held in the tropics and based on Amin et al (2020) one would expect that the rice plants with their longer roots would accessed access the more stable and older water stores in deeper subsurface zones below $60 \mathrm{~cm}$. Instead, the rice plants in the different treatments preferably consumed the temporally variable and isotopically labeled newer surface soil water similarly to what has been documented in natural ecosystems (e.g. van der Velde et al., 2015) and temperate grasslands (Bachmann et al., 2015).

By mixing biochar in the top soil, a multi-layer soil profile was created and based on studies in natural 
different quantities of water but also water characterized by different ages. Performing additional isotopic experiments (Beyer et al., 2016), higher temporal resolution sampling of plant water (Marshall et al., 2020; Volkmann et al., 2016) and spatiotemporal soil water (Sprenger et al., 2015) or including interception, transpiration and atmospheric processes into the experimental analysis (JiménezRodríguez et al., 2020) would allow to not only distinguish in more detail whether the rice plants prefer bounded or mobile water (Berry et al., 2018; Brooks et al., 2010; McDonnell, 2014) but also to quantify the fraction of water sources (Muñoz-Villers et al., 2020). Consequently, this would also allow to indicate how long the soil water resides in the different soil layers before it is consumed by plants. In addition to the aforementioned vertical processes also the lateral water fluxes (Sprenger and Allen, 2020) need to be considered to assess the field-scale responses to biochar amendments (Fischer et al., 2018). These analyses are beyond the scope of this initial investigation; however, our results indicate that rice plants growing in biochar amended soils not only had access to more water (Figure 4) but also had a more stable source of green water (i.e. soil moisture from rainfall) and thus could withstand dry spells seven days longer (Figure 3). Regardless of the potential advantages, as stated by Fischer et al. (2018), it must be noted that biochar as water management tool does not adhere to a one size fits all approach but needs fine tuning in accordance with climate, site and plant characteristics to obtain stable and optimal yields.

\section{Conclusions}

Amending soils with biochar is an emerging and promising practice to improving resilience of rainfed agriculture to climate variability by increasing the soil water and plant available water. Using an experimental field study, we observed biochar amendments to create generally $2 \%$ to $7 \%$ higher soil water content and therefore more plant water relative to the control treatment, despite differing impacts between biochar treatments depending on the type of biochar and timing of application. In addition, we observed a within treatment variability in the soil water retention curves which was in the same order of magnitude as one would expect from responses due to differences in biochar application rates or due to differences in biochar typologies. Further, we were able to trace the effect of biochar on the soil water storage to investigate which water plants consume. The isotopic composition of soil water sampled in 
562 isotopic composition of rainfall. The stable isotope composition of plant water instead showed that the rice plants preferably consumed the temporal variable soil water comprised of residual rainfall the experienced evaporation in the top $20 \mathrm{~cm}$ of the soil. When comparing the different treatments, our results indicated that rice plants grown in biochar amended soils not only had more water available but also had a more stable source of green water. Thus, these rice plants in biochar amended soils could withstand dry spells of up to an extra seven days. Despite these positive effects of biochar amendment, it still seems necessary to provide additional irrigation to facilitate optimal plant growth if extended dry periods occur during certain growing stages to have optimal yields. So, while our study highlights some of the usefulness of combining hydrometric and isotopic data to map out how biochar additions impact

571 plant-water interactions in the field, we acknowledge more work is needed to fully characterize the influence biochar additions may have at scale on agroecosystems. This further understanding is important given the need of more specific management recommendations to ensure biochar additions in agricultural landscapes result in net benefits for both farmers and the environment.

\title{
Data availability
}

Upon acceptance, all of the research data that were required to create the plots will be available from the Bolin Center for Climate Research.

\section{Author contribution}

BF, LM, MG, SM, MJ, AS and SL designed the experiment, and BF, JR carried it out. CC provided $\mathrm{BC} 2$, RS analyzed the stable isotope composition of the collected water. BF performed the data analysis and prepared the paper with contributions from all co-authors.

\section{Competing interests}

The authors declare that they have no conflict of interest.

\section{Acknowledgements}

\author{
We thank all the people who helped in the field and the laboratory, particularly Sharon Arce, Johnny
} Arriola and Eduardo Rodríguez and all the HIDROCEC team of Universidad Nacional, Liberia, Costa 
587 Rica. The authors would also like to thank the collaboration from the Stable Isotopes Research Group

588 \& Water Resources Management Laboratory (Universidad Nacional, Heredia) on helping with the lysimeters and wells installation as well as water stable isotopes. Especially Edwin Quirós Ramos, Roberto Ramírez, Juan Carlos Jiménez Vargas and all technical staff from the EEEJN-INTA who help

591 develop the experimental design and advised about regional crop management practices and Dr. Jaime Quesada from TEC for providing the biochar national used in this study.

\section{Financial support}

594 This research was conducted as part of the Agricultural Water Innovations in the Tropics (AgWIT) 595 project funded by the Joint Call of the Water Joint Programming Initiative (Water JPI) and the Joint Programming Initiative on Agriculture, Food Security and Climate Change (FACCE-JPI) of the European Union and partner countries. Stefano Manzoni and Steve Lyon acknowledge partial support

598 from the Swedish Research Agencies Vetenskapsrådet, Formas, and Sida through the joint call on 599 Sustainability and resilience-Tackling climate and environmental changes (grant VR 2016-06313), and 600 the Bolin Centre for Climate Research (Research Area 7). Ricardo Sánchez-Murillo acknowledges the 601 financial support from the International Atomic Energy Agency (IAEA) grants COS/7/005, RC-19747

602 (CRP-F31004), RC-22760 (CRP-F33024) which were fundamental to conduct the water stable isotope 603 analysis in Costa Rica. 


\section{References}

Agegnehu, G., Srivastava, A. K. and Bird, M. I.: The role of biochar and biochar-compost in improving soil quality and crop performance: A review, Applied Soil Ecology, 119, 156-170, doi:10.1016/j.apsoil.2017.06.008, 2017.

Allen, R. G., Pereira, L. S., Raes, D. and Smith, M.: Crop evapotranspiration-Guidelines for computing crop water requirements, FAO, Rome., 1998.

Allen, S. T., Kirchner, J. W., Braun, S., Siegwolf, R. T. W. and Goldsmith, G. R.: Seasonal origins of soil water used by trees, Hydrol. Earth Syst. Sci., 23(2), 1199-1210, doi:10.5194/hess-23-1199$2019,2019$.

Amin, A., Zuecco, G., Geris, J., Schwendenmann, L., McDonnell, J. J., Borga, M. and Penna, D.: Depth distribution of soil water sourced by plants at the global scale: A new direct inference approach, Ecohydrology, 13(2), e2177, doi:10.1002/eco.2177, 2020.

Bachmann, D., Gockele, A., Ravenek, J. M., Roscher, C., Strecker, T., Weigelt, A. and Buchmann, N.: No Evidence of Complementary Water Use along a Plant Species Richness Gradient in Temperate Experimental Grasslands, PLOS ONE, 10(1), 1-14, doi:10.1371/journal.pone.0116367, 2015.

Batool, A., Taj, S., Rashid, A., Khalid, A., Qadeer, S., Saleem, A. R. and Ghufran, M. A.: Potential of soil amendments (Biochar and Gypsum) in increasing water use efficiency of Abelmoschus esculentus L. Moench, Frontiers in Plant Science, 6(September), 1-13, doi:10.3389/fpls.2015.00733, 2015 .

Benettin, P., Volkmann, T. H. M., von Freyberg, J., Frentress, J., Penna, D., Dawson, T. E. and Kirchner, J. W.: Effects of climatic seasonality on the isotopic composition of evaporating soil waters, Hydrology and Earth System Sciences, 22(5), 2881-2890, doi:10.5194/hess-22-2881$2018,2018$.

Berry, Z. C., Evaristo, J., Moore, G., Poca, M., Steppe, K., Verrot, L., Asbjornsen, H., Borma, L. S., Bretfeld, M., Hervé-Fernández, P., Seyfried, M., Schwendenmann, L., Sinacore, K., De Wispelaere, L. and McDonnell, J.: The two water worlds hypothesis: Addressing multiple working hypotheses and proposing a way forward, Ecohydrology, 11(3), e1843, doi:10.1002/eco.1843, 2018.

Beyer, M., Koeniger, P., Gaj, M., Hamutoko, J. T., Wanke, H. and Himmelsbach, T.: A deuteriumbased labeling technique for the investigation of rooting depths, water uptake dynamics and unsaturated zone water transport in semiarid environments, Journal of Hydrology, 533, 627643, doi:10.1016/j.jhydrol.2015.12.037, 2016.

Biazin, B., Sterk, G., Temesgen, M., Abdulkedir, A. and Stroosnijder, L.: Rainwater harvesting and management in rainfed agricultural systems in sub-Saharan Africa - A review, Physics and Chemistry of the Earth, Parts A/B/C, 47-48, 139-151, doi:10.1016/j.pce.2011.08.015, 2012.

Birkel, C., Brenes, A. and Sánchez-Murillo, R.: The Tempisque-Bebedero catchment system: energywater-food consensus in the seasonally dry tropics of northwestern Costa Rica, in Nexus Outlook: assessing resource use challenges in the water, energy and food nexus, TH-Koeln, University of Applied Sciences. [online] Available from: https://www.water-energy- 
food.org/fileadmin/user_upload/files/documents/others/OutlookNexus_Assessing_Resource_Use_Challenges.pdf, 2017.

Blanco-Canqui, H.: Biochar and Soil Physical Properties, Soil Science Society of America Journal, 81(4), 687, doi:10.2136/sssaj2017.01.0017, 2017.

Brooks, R. J., Barnard, H. R., Coulombe, R. and McDonnell, J. J.: Ecohydrologic separation of water between trees and streams in a Mediterranean climate, Nature Geoscience, 3(2), 100-104, doi:10.1038/ngeo722, 2010.

Castelli, G., Bresci, E., Castelli, F., Hagos, E. Y. and Mehari, A.: A participatory design approach for modernization of spate irrigation systems, Agricultural Water Management, 210, 286-295, doi: 10.1016/j.agwat.2018.08.030, 2018.

Craig, H.: Isotopic Variations in Meteoric Waters, Science, 133(3465), 1702-1703, doi:10.1126/science.133.3465.1702, 1961 .

Dansgaard, W.: Stable isotopes in precipitation, Tellus, 16(4), 436-468, doi:10.1111/j.21533490.1964.tb00181.x, 1964.

Dawson, T. E. and Ehleringer, J. R.: Streamside trees that do not use stream water, Nature, 350(6316), 335-337, doi:10.1038/350335a0, 1991.

Diogenes Cubero, F. and Maria José Elizondo, A.: Estudio detallado de suelos y capacidad de uso de las tierras de estación experimental enrique jiménez núñez (Detailed study of soils and capacity of use of the lands of experimental station enrique jiménez núñez), Instituto Nacional de Innovación y Transferencia en Tecnología Agropecuaria, Cañas., 2014.

Enfors, E. I. I. and Gordon, L. J. J.: Analysing resilience in dryland agro-ecosystems: a case study of the Makanya catchment in Tanzania over the past 50 years, Land Degradation \& Development, 18(6), 680-696, doi:10.1002/ldr.807, 2007.

Falkenmark, M.: Society's interaction with the water cycle: a conceptual framework for a more holistic approach, Hydrological Sciences Journal, 42(4), 451-466, doi:10.1080/02626669709492046, 1997.

Famiglietti, J. S.: The global groundwater crisis, Nature Climate Change, 4(11), 945-948, doi:10.1038/nclimate2425, 2014.

Feng, X., Porporato, A. and Rodriguez-Iturbe, I.: Changes in rainfall seasonality in the tropics, Nature Climate Change, 3(9), 811-815, doi:10.1038/nclimate1907, 2013.

Fischer, B. M. C., Mul, M. L. and Savenije, H. H. G.: Determining spatial variability of dry spells: a Markov-based method, applied to the Makanya catchment, Tanzania, Hydrology and Earth System Sciences, 17(6), 2161-2170, doi:10.5194/hess-17-2161-2013, 2013.

Fischer, B. M. C., Stähli, M. and Seibert, J.: Pre-event water contributions to runoff events of different magnitude in pre-alpine headwaters, Hydrology Research, 48(1), 28-47, doi:10.2166/nh.2016.176, 2017a.

Fischer, B. M. C., van Meerveld, H. J. (Ilja) and Seibert, J.: Spatial variability in the isotopic composition of rainfall in a small headwater catchment and its effect on hydrograph separation, Journal of Hydrology, 547, 755-769, doi:10.1016/j.jhydrol.2017.01.045, 2017b. 
Fischer, B. M. C., Manzoni, S., Morillas, L., Garcia, M., Johnson, M. S. and Lyon, S. W.: Improving agricultural water use efficiency with biochar - A synthesis of biochar effects on water storage and fluxes across scales, Science of The Total Environment, doi: 10.1016/j.scitotenv.2018.11.312, 2018.

Fischer, B. M. C., Aemisegger, F., Graf, P., Sodemann, H. and Seibert, J.: Assessing the Sampling Quality of a Low-Tech Low-Budget Volume-Based Rainfall Sampler for Stable Isotope Analysis, Frontiers in Earth Science, 7, 244, doi:10.3389/feart.2019.00244, 2019.

Fraiture, C. de and Wichelns, D.: Satisfying future water demands for agriculture, Agricultural Water Management, 97(4), 502-511, doi: 10.1016/j.agwat.2009.08.008, 2010.

Fraiture, C. de, Karlberg, L. and Rockström, J.: Can rainfed agriculture feed the world? An assessment of potentials and risk, in Rainfed agriculture: Unlocking the potential., pp. 124-132, CAB International, London., 2009.

Gat, J. R. and Airey, P. L.: Stable water isotopes in the atmosphere/biosphere/lithosphere interface: Scaling-up from the local to continental scale, under humid and dry conditions, Global and Planetary Change, 51(1), 25-33, doi:10.1016/j.gloplacha.2005.12.004, 2006.

Gibson, J. J., Birks, S. J. and Yi, Y.: Stable isotope mass balance of lakes: a contemporary perspective, Quaternary Science Reviews, 131, 316-328, doi:10.1016/j.quascirev.2015.04.013, 2016.

Giorgi, F.: Climate change hot-spots, Geophysical Research Letters, 33(8), doi:10.1029/2006GL025734, 2006.

Gląb, T., Palmowska, J., Zaleski, T. and Gondek, K.: Effect of biochar application on soil hydrological properties and physical quality of sandy soil, Geoderma, 281, 11-20, doi:10.1016/j.geoderma.2016.06.028, 2016.

Goldsmith, G. R., Muñoz-Villers, L. E., Holwerda, F., McDonnell, J. J., Asbjornsen, H. and Dawson, T. E.: Stable isotopes reveal linkages among ecohydrological processes in a seasonally dry tropical montane cloud forest, Ecohydrology, 5(6), 779-790, doi:10.1002/eco.268, 2012.

Gonfiantini, R.: Chapter 3 - environmental isotopes in lake studies, in The Terrestrial Environment, B, edited by P. Fritz and J. C. Fontes, pp. 113-168, Elsevier, Amsterdam., 1986.

Hidalgo, H. G., Alfaro, E. J., Amador, J. A. and Bastidas, Á.: Precursors of quasi-decadal dry-spells in the Central America Dry Corridor, Climate Dynamics, 53(3), 1307-1322, doi:10.1007/s00382019-04638-y, 2019.

Iiyama, I.: Differences between field-monitored and laboratory-measured soil moisture characteristics, Soil Science and Plant Nutrition, 62(5-6), 416-422, doi:10.1080/00380768.2016.1242367, 2016.

Imbach, P., Chou, S. C., Lyra, A., Rodrigues, D., Rodriguez, D., Latinovic, D., Siqueira, G., Silva, A., Garofolo, L. and Georgiou, S.: Future climate change scenarios in Central America at high spatial resolution, PLOS ONE, 13(4), e0193570, doi:10.1371/journal.pone.0193570, 2018.

Jasechko, S., Perrone, D., Befus, K. M., Bayani Cardenas, M., Ferguson, G., Gleeson, T., Luijendijk, E., McDonnell, J. J., Taylor, R. G., Wada, Y. and Kirchner, J. W.: Global aquifers dominated by fossil groundwaters but wells vulnerable to modern contamination, Nature Geoscience, 10(6), 425-429, doi:10.1038/ngeo2943, 2017. 
Jeffery, S., Meinders, M. B. J., Stoof, C. R., Bezemer, T. M., van de Voorde, T. F. J., Mommer, L. and van Groenigen, J. W.: Biochar application does not improve the soil hydrological function of a sandy soil, Geoderma, 251-252, 47-54, doi:10.1016/j.geoderma.2015.03.022, 2015.

Jeffery, S., Abalos, D., Prodana, M., Bastos, A. C., Van Groenigen, J. W., Hungate, B. A. and Verheijen, F.: Biochar boosts tropical but not temperate crop yields, Environmental Research Letters, 12(5), doi:10.1088/1748-9326/aa67bd, 2017.

Jiménez-Rodríguez, C. D., Coenders-Gerrits, M., Wenninger, J., Gonzalez-Angarita, A. and Savenije, H.: Contribution of understory evaporation in a tropical wet forest during the dry season, Hydrol. Earth Syst. Sci., 24(4), 2179-2206, doi:10.5194/hess-24-2179-2020, 2020.

Kätterer, T., Roobroeck, D., Andrén, O., Kimutai, G., Karltun, E., Kirchmann, H., Nyberg, G., Vanlauwe, B. and Röing de Nowina, K.: Biochar addition persistently increased soil fertility and yields in maize-soybean rotations over 10 years in sub-humid regions of Kenya, Field Crops Research, 235, 18-26, doi:10.1016/j.fcr.2019.02.015, 2019.

Klaus, J. and McDonnell, J. J.: Hydrograph separation using stable isotopes: Review and evaluation, Journal of Hydrology, 505, 47-64, doi:10.1016/j.jhydrol.2013.09.006, 2013.

Knutson, T. R., Delworth, T. L., Dixon, K. W., Held, I. M., Lu, J., Ramaswamy, V., Schwarzkopf, M. D., Stenchikov, G. and Stouffer, R. J.: Assessment of Twentieth-Century Regional Surface Temperature Trends Using the GFDL CM2 Coupled Models, J. Climate, 19(9), 1624-1651, doi:10.1175/JCLI3709.1, 2006.

Koeniger, P., Marshall, J. D., Link, T. and Mulch, A.: An inexpensive, fast, and reliable method for vacuum extraction of soil and plant water for stable isotope analyses by mass spectrometry, Rapid Communications in Mass Spectrometry, 25(20), 3041-3048, doi:10.1002/rcm.5198, 2011.

Koeniger, P., Gaj, M., Beyer, M. and Himmelsbach, T.: Review on soil water isotope-based groundwater recharge estimations, Hydrological Processes, 30(16), 2817-2834, doi:10.1002/hyp.10775, 2016.

Lim, T.-J. and Spokas, K.: Impact of Biochar Particle Shape and Size on Saturated Hydraulic Properties of Soil, Korean Journal of Environmental Agriculture, 37(1), 1-8, doi:KJEA-37-1, 2018.

Liu, C., Wang, H., Tang, X., Guan, Z., Reid, B. J., Rajapaksha, A. U., Ok, Y. S. and Sun, H.: Biochar increased water holding capacity but accelerated organic carbon leaching from a sloping farmland soil in China, Environmental Science and Pollution Research, 23(2), 995-1006, doi:10.1007/s11356-015-4885-9, 2016.

Liu, Z., Dugan, B., Masiello, C. A. and Gonnermann, H. M.: Biochar particle size, shape, and porosity act together to influence soil water properties, PLOS ONE, 12(6), 1-19, doi:10.1371/journal.pone.0179079, 2017.

Magaña, V., Amador, J. A. and Medina, S.: The Midsummer Drought over Mexico and Central America, J. Climate, 12(6), 1577-1588, doi:10.1175/15200442(1999)012<1577:TMDOMA>2.0.CO;2, 1999.

Mahindawansha, A., Orlowski, N., Kraft, P., Rothfuss, Y., Racela, H. and Breuer, L.: Quantification of plant water uptake by water stable isotopes in rice paddy systems, Plant and Soil, 429(1), 281302, doi:10.1007/s11104-018-3693-7, 2018. 
Makurira, H., Mul, M. L., Vyagusa, N. F., Uhlenbrook, S. and Savenije, H. H. G.: Evaluation of community-driven smallholder irrigation in dryland South Pare Mountains, Tanzania: A case study of Manoo micro dam, Physics and Chemistry of the Earth, Parts A/B/C, 32(15-18), 10901097, doi: 10.1016/j.pce.2007.07.020, 2007.

Marshall, J., Cuntz, M., Beyer, M., Dubbert, M. and Kuehnhammer, K.: Borehole Equilibration: Testing a New Method to Monitor the Isotopic Composition of Tree Xylem Water in situ, Frontiers in Plant Science, 11, doi:10.3389/fpls.2020.00358, 2020.

McDonnell, J. J.: The two water worlds hypothesis: ecohydrological separation of water between streams and trees?, WIREs Water, 1(4), 323-329, doi:10.1002/wat2.1027, 2014.

Merlivat, L.: Molecular diffusivities of H2 16O, HD16O, and H2 $18 \mathrm{O}$ in gases, J. Chem. Phys., 69(6), 2864-2871, doi:10.1063/1.436884, 1978.

Morgan, K. T., Parsons, L. R. and Adair Wheaton, T.: Comparison of laboratory- and field-derived soil water retention curves for a fine sand soil using tensiometric, resistance and capacitance methods, Plant and Soil, 234(2), 153-157, doi:10.1023/A:1017915114685, 2001.

Morillas, L., Hund, S. V. and Johnson, M. S.: Water Use Dynamics in Double Cropping of Rainfed Upland Rice and Irrigated Melons Produced Under Drought-Prone Tropical Conditions, Water Resources Research, 55(5), 4110-4127, doi:10.1029/2018WR023757, 2019.

Muñoz-Villers, L. E., Geris, J., Alvarado-Barrientos, M. S., Holwerda, F. and Dawson, T.: Coffee and shade trees show complementary use of soil water in a traditional agroforestry ecosystem, Hydrology and Earth System Sciences, 24(4), 1649-1668, doi:10.5194/hess-24-1649-2020, 2020.

Mutiro, J., Makurira, H., Senzanje, A. and Mul, M. L.: Water productivity analysis for smallholder rainfed systems: A case study of Makanya catchment, Tanzania, Physics and Chemistry of the Earth, Parts A/B/C, 31(15-16), 901-909, doi:10.1016/j.pce.2006.08.019, 2006.

Narseh Kumar, M., Murthy, C. S., Sesha Sai, M. V. R. and Roy, P. S.: On the use of Standardized Precipitation Index (SPI) for drought intensity assessment, Meteorological Applications, 16(3), 381-389, doi:10.1002/met.136, 2009.

Nelissen, V., Ruysschaert, G., Manka Abusi, D., D’ Hose, T., De Beuf, K., Al-Barri, B., Cornelis, W. and Boeckx, P.: Impact of a woody biochar on properties of a sandy loam soil and spring barley during a two-year field experiment, European Journal of Agronomy, 62, 65-78, doi:10.1016/j.eja.2014.09.006, 2015.

Novak, J., Ro, K., Ok, Y. S., Sigua, G., Spokas, K., Uchimiya, S. and Bolan, N.: Biochars multifunctional role as a novel technology in the agricultural, environmental, and industrial sectors, Chemosphere, 142, 1-3, doi:10.1016/j.chemosphere.2015.06.066, 2016.

Obia, A., Mulder, J., Martinsen, V., Cornelissen, G. and Børresen, T.: In situ effects of biochar on aggregation, water retention and porosity in light-textured tropical soils, Soil and Tillage Research, 155, 35-44, doi:10.1016/j.still.2015.08.002, 2016.

Omondi, M. O., Xia, X., Nahayo, A., Liu, X., Korai, P. K. and Pan, G.: Quantification of biochar effects on soil hydrological properties using meta-analysis of literature data, Geoderma, 274, 28-34, doi:10.1016/j.geoderma.2016.03.029, 2016. 
Penna, D., Hopp, L., Scandellari, F., Allen, S. T., Benettin, P., Beyer, M., Geris, J., Klaus, J., Marshall, J. D., Schwendenmann, L., Volkmann, T. H. M., von Freyberg, J., Amin, A., Ceperley, N., Engel, M., Frentress, J., Giambastiani, Y., McDonnell, J. J., Zuecco, G., Llorens, P., Siegwolf, R. T. W., Dawson, T. E. and Kirchner, J. W.: Ideas and perspectives: Tracing terrestrial ecosystem water fluxes using hydrogen and oxygen stable isotopes - challenges and opportunities from an interdisciplinary perspective, Biogeosciences, 15(21), 6399-6415, doi:10.5194/bg-15-6399-2018, 2018.

Penna, D., Geris, J., Hopp, L. and Scandellari, F.: Water sources for root water uptake: Using stable isotopes of hydrogen and oxygen as a research tool in agricultural and agroforestry systems, Agriculture, Ecosystems \& Environment, 291, 106790, doi:10.1016/j.agee.2019.106790, 2020.

Prechsl, U. E., Gilgen, A. K., Kahmen, A. and Buchmann, N.: Reliability and quality of water isotope data collected with a low-budget rain collector, Rapid Communications in Mass Spectrometry, 28(8), 879-885, doi:10.1002/rcm.6852, 2014.

Reyes-Cabrera, J., Erickson, J. E., Leon, R. G., Silveira, M. L., Rowland, D. L., Sollenberger, L. E. and Morgan, K. T.: Converting bahiagrass pasture land to elephantgrass bioenergy production enhances biomass yield and water quality, Agriculture, Ecosystems and Environment, 248(July), 20-28, doi:10.1016/j.agee.2017.07.021, 2017.

Rockström, J.: On-farm green water estimates as a tool for increased food production in water scarce regions, Physics and Chemistry of the Earth, Part B: Hydrology, Oceans and Atmosphere, 24(4), 375-383, doi:10.1016/S1464-1909(99)00016-7, 1999.

Rothfuss, Y. and Javaux, M.: Reviews and syntheses: Isotopic approaches to quantify root water uptake: a review and comparison of methods, Biogeosciences, 14(8), 2199-2224, doi:10.5194/bg-142199-2017, 2017.

Sánchez-Murillo, R. and Birkel, C.: Groundwater recharge mechanisms inferred from isoscapes in a complex tropical mountainous region, Geophysical Research Letters, 43(10), 5060-5069, doi:10.1002/2016GL068888, 2016.

Sánchez-Murillo, R., Esquivel-Hernándezv, G., Birkel, C., Correa, A., Welsh, K., Durán-Quesada, A. M., Sánchez-Gutiérrez, R. and Poca, M.: Tracing water sources and fluxes in a dynamic tropical environment: from observations to modelingv, Frontiers in Earth Science, in review.

Sánchez-Murillo, R., Birkel, C., Welsh, K., Esquivel-Hernández, G., Corrales-Salazar, J., Boll, J., Brooks, E., Roupsard, O., Sáenz-Rosales, O., Katchan, I., Arce-Mesén, R., Soulsby, C. and Araguás-Araguás, L. J.: Key drivers controlling stable isotope variations in daily precipitation of Costa Rica: Caribbean Sea versus Eastern Pacific Ocean moisture sources, Quaternary Science Reviews, 131, 250-261, doi:10.1016/j.quascirev.2015.08.028, 2016.

Sánchez-Murillo, R., Durán-Quesada, A. M., Birkel, C., Esquivel-Hernández, G. and Boll, J.: Tropical precipitation anomalies and d-excess evolution during El Niño 2014-16, Hydrological Processes, 31(4), 956-967, doi:10.1002/hyp.11088, 2017.

Sánchez-Murillo, R., Esquivel-Hernández, G., Corrales-Salazar, J. L., Castro-Chacón, L., DuránQuesada, A. M., Guerrero-Hernández, M., Delgado, V., Barberena, J., Montenegro-Rayo, K., Calderón, H., Chevez, C., Peña-Paz, T., García-Santos, S., Ortiz-Roque, P., Alvarado-Callejas, Y., Benegas, L., Hernández-Antonio, A., Matamoros-Ortega, M., Ortega, L. and Terzer- 

Isthmus, Hydrological Processes, 34(11), 2660-2675, doi:10.1002/hyp.13758, 2020.

Saxena, R.: Oxygen-18 fractionation in nature and estimation of groundwater recharge [Rayleigh distillation formula, reverse Rayleigh process, throughfall], Report-University of Uppsala, Department of Physical Geography, Hydrological Division Series A (Sweden), 1987.

Shen, Y. J., Zhang, Z. B., Gao, L. and Peng, X.: Evaluating contribution of soil water to paddy rice by stable isotopes of hydrogen and oxygen, Paddy and Water Environment, 13(1), 125-133, doi:10.1007/s10333-013-0414-y, 2015.

Sprenger, M. and Allen, S. T.: What Ecohydrologic Separation Is and Where We Can Go With It, Water Resources Research, 56(7), e2020WR027238, doi:10.1029/2020WR027238, 2020.

Sprenger, M., Herbstritt, B. and Weiler, M.: Established methods and new opportunities for pore water stable isotope analysis, Hydrological Processes, 29(25), 5174-5192, doi:10.1002/hyp.10643, 2015.

Sprenger, M., Leistert, H., Gimbel, K. and Weiler, M.: Illuminating hydrological processes at the soilvegetation-atmosphere interface with water stable isotopes, Reviews of Geophysics, 54(3), 674-704, doi:10.1002/2015RG000515, 2016.

Sprenger, M., Tetzlaff, D. and Soulsby, C.: Soil water stable isotopes reveal evaporation dynamics at the soil-plant-atmosphere interface of the critical zone, Hydrol. Earth Syst. Sci., 21(7), 38393858, doi:10.5194/hess-21-3839-2017, 2017.

Stumpp, C., Maloszewski, P., Stichler, W. and Fank, J.: Environmental isotope ( $818 \mathrm{O})$ and hydrological data to assess water flow in unsaturated soils planted with different crops: Case study lysimeter station "Wagna" (Austria), Journal of Hydrology, 369(1), 198-208, doi:10.1016/j.jhydrol.2009.02.047, 2009.

Sun, F. and Lu, S.: Biochars improve aggregate stability, water retention, and pore-space properties of clayey soil, Journal of Plant Nutrition and Soil Science, 177(1), 26-33, doi:10.1002/jpln.201200639, 2014.

Sundberg, C., Karltun, E., Gitau, J. K., Kätterer, T., Kimutai, G. M., Mahmoud, Y., Njenga, M., Nyberg, G., Roing de Nowina, K., Roobroeck, D. and Sieber, P.: Biochar from cookstoves reduces greenhouse gas emissions from smallholder farms in Africa, Mitigation and Adaptation Strategies for Global Change, doi:10.1007/s11027-020-09920-7, 2020.

Van Genuchten, M. T.: A closed-form equation for predicting the hydraulic conductivity of unsaturated soils, Soil science society of America journal, 44(5), 892-898, 1980.

van der Velde, Y., Heidbüchel, I., Lyon, S. W., Nyberg, L., Rodhe, A., Bishop, K. and Troch, P. A.: Consequences of mixing assumptions for time-variable travel time distributions: Mixing assumptions and time-variable travel time distributions, Hydrological Processes, 29(16), 3460 3474, doi:10.1002/hyp.10372, 2015.

Vico, G. and Brunsell, N. A.: Tradeoffs between water requirements and yield stability in annual vs. perennial crops, Advances in Water Resources, 112, 189-202, doi: 10.1016/j.advwatres.2017.12.014, 2018. 
Vico, G. and Porporato, A.: Ecohydrology of Agroecosystems: Quantitative Approaches Towards Sustainable Irrigation, Bulletin of Mathematical Biology, 77(2), 298-318, doi:10.1007/s11538014-9988-9, 2015.

Volkmann, T. H. M., Kühnhammer, K., Herbstritt, B., Gessler, A. and Weiler, M.: A method for in situ monitoring of the isotope composition of tree xylem water using laser spectroscopy, Plant, Cell \& Environment, 39(9), 2055-2063, doi:10.1111/pce.12725, 2016.

Zhang, D., Yan, M., Niu, Y., Liu, X., van Zwieten, L., Chen, D., Bian, R., Cheng, K., Li, L., Joseph, S., Zheng, J., Zhang, X., Zheng, J., Crowley, D., Filley, T. R. and Pan, G.: Is current biochar research addressing global soil constraints for sustainable agriculture?, Agriculture, Ecosystems \& Environment, 226, 25-32, doi:10.1016/j.agee.2016.04.010, 2016. 
https://doi.org/10.5194/hess-2020-404

\section{Table}

Table 1 Response ratios for wilting point $\left(\theta_{W P}\right)$, minimum observed average volumetric soil moisture contents $\left(\theta_{\text {min }}\right)$ field capacity $\left(\theta_{F C}\right)$, and for the van Genuchten parameters $\alpha$ and $n$ (Equation 1) for BC1 and BC2. Parameters are derived for the average soil water retention curve of figure 4 for Periods I-III. A response ratio RR $>1$ indicates that biochar has a positive effect on a soil water content while a $R R \approx 1$ indicates that biochar has no effect, 899 while $R R<1$ indicates a negative response for the variable of interest.

\begin{tabular}{c|c|c|c|c} 
& BC & Period I & Period II & Period III \\
\hline$\theta_{\mathrm{WP} \mathrm{BC}} \theta_{\mathrm{WP} \mathrm{C}}{ }^{-1}$ & 1 & 1.36 & 1.46 & 1.18 \\
\cline { 2 - 5 } & 2 & 1.16 & 1.32 & 1.03 \\
\hline$\theta_{\operatorname{min~BC}} \theta_{\min \mathrm{C}^{-1}}$ & 1 & 1.12 & 1.16 & 1.17 \\
\cline { 2 - 5 } & 2 & 1.08 & 1.03 & 1.11 \\
\hline$\theta_{\mathrm{FC} \mathrm{BC}} \theta_{\mathrm{FC} \mathrm{C}}{ }^{-1}$ & 1 & 1.08 & 1.14 & 1.04 \\
\cline { 2 - 5 } & 2 & 1.13 & 1.13 & 0.88 \\
\hline$\alpha_{\mathrm{BC}} \alpha_{\mathrm{C}^{-1}}$ & 1 & 1.29 & 0.50 & 0.68 \\
\cline { 2 - 5 } & 2 & 3.21 & 1.34 & 1.08 \\
\hline $\mathrm{n}_{\mathrm{BC}} \mathrm{n}_{\mathrm{C}}{ }^{-1}$ & 1 & 1.00 & 0.89 & 1.47 \\
\cline { 2 - 5 } & 2 & 1.00 & 0.92 &
\end{tabular}


https://doi.org/10.5194/hess-2020-404

Preprint. Discussion started: 20 August 2020

(c) Author(s) 2020. CC BY 4.0 License.

901 Figures

a)

c) b)<smiles>[10BH2]</smiles>

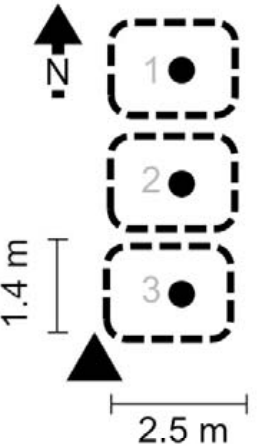

C

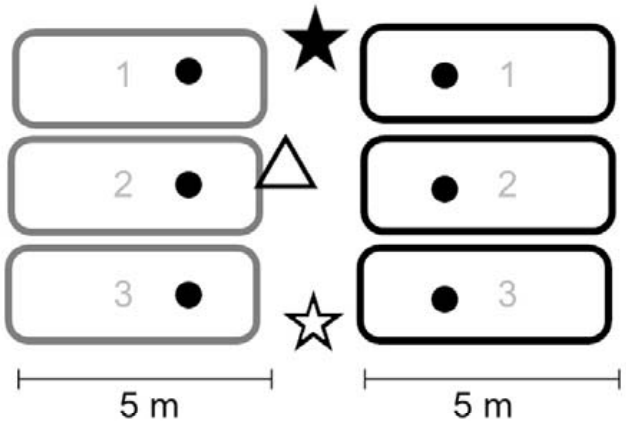

Volumetric water content

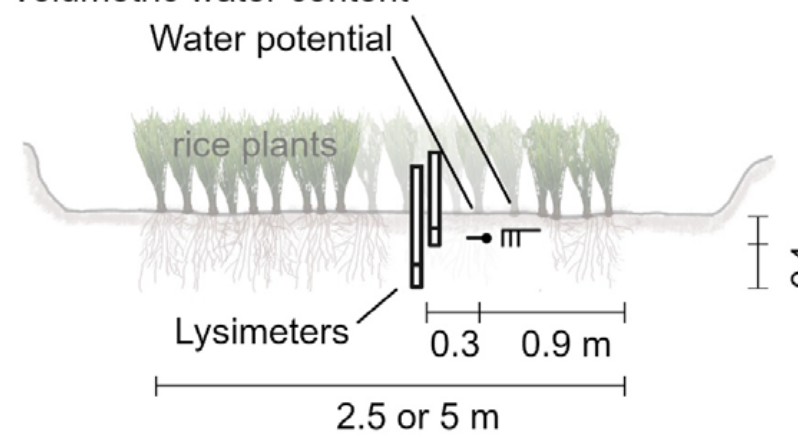

$\triangle$ ground water well A

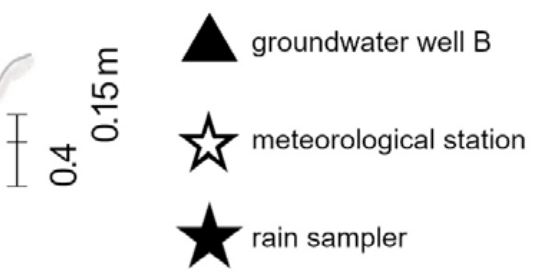

sensors see side view c)

902

903

904

905

906

907

908

909

Figure 1 (a) Map of Costa Rica with location of the experimental site (orange circle), (b) schematic top view of the rice experiment with the three different treatment sections, BC1, BC2 and C. Symbols indicate the different instruments: rain sampler for stable isotope samples (filled star), meteorological station (open star), continues groundwater level measurements in well A (open triangle), groundwater well B for stable isotope samples (closed triangle) and (c) a schematic side view of a plot with suction lysimeters for stable isotope samples $15 \mathrm{~cm}$ and $40 \mathrm{~cm}$ below the surface, the water potential and volumetric water content sensors. 

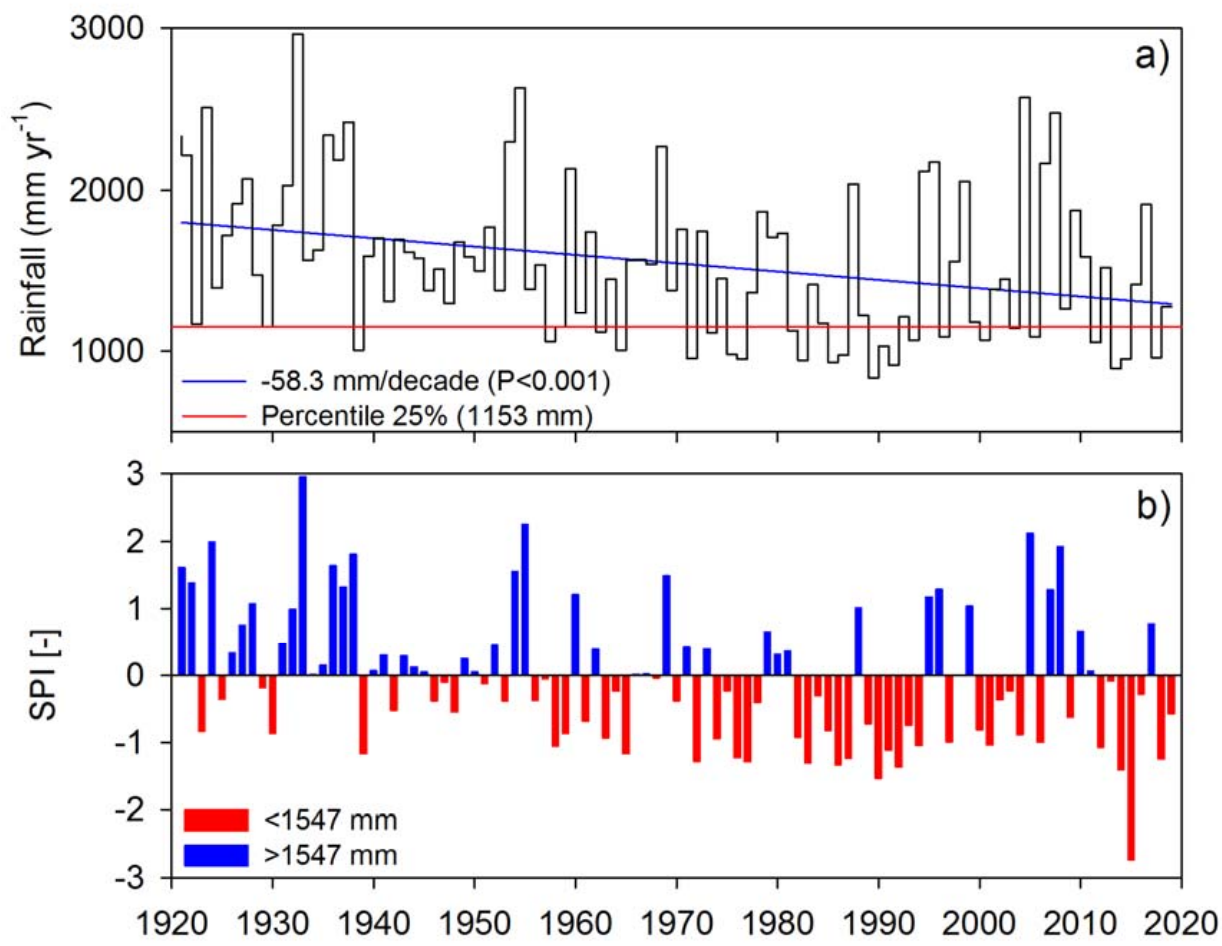

Figure 2 (a) Long-term rainfall ( $\mathrm{mm} \mathrm{yr}^{-1}$ ) including a significant rainfall decrease of $-53 \mathrm{~mm}$ per decade (blue line) and $25 \%$ percentile of $1153 \mathrm{~mm}$ (red line as reference) and b) Standardized Precipitation Index (SPI) within the lowlands of Guanacaste between 1921-2019 (Long-term rainfall average $=1547 \pm 473 \mathrm{~mm} \mathrm{yr}^{-1}$ )(Rainfall data source: Ing. Werner Hagnauer, Cañas, Guanacaste). 
https://doi.org/10.5194/hess-2020-404

Preprint. Discussion started: 20 August 2020

(c) Author(s) 2020. CC BY 4.0 License.
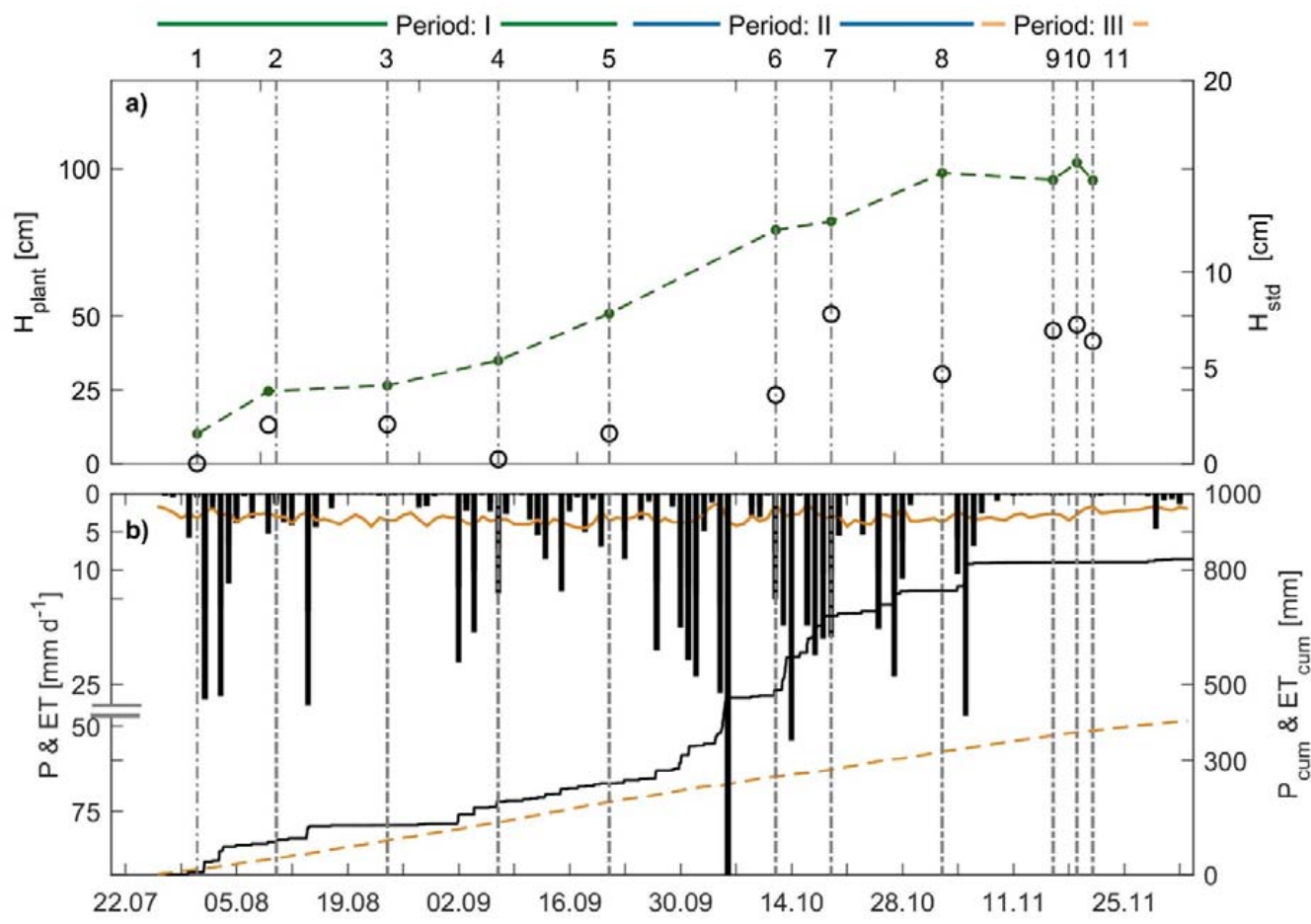

Figure 3 Time series of (a) rice plant average height $\left(H_{\text {plant }}\right)$ of the rice plants (filled green circles and dashed line) and the standard deviation the plant height (open black circles); b) precipitation (P, black bars), estimated evapotranspiration (ET, solid orange line), accumulated P (solid black line) and accumulated ET (orange dashed line). The different water sampling days 1-11 are indicated in each panel as vertical dashed lines and numbered on top of panel a and the date are given on the $x$-axis of panel b as dd.mm. Period I, II and III are indicated on the top of panel $c$. 

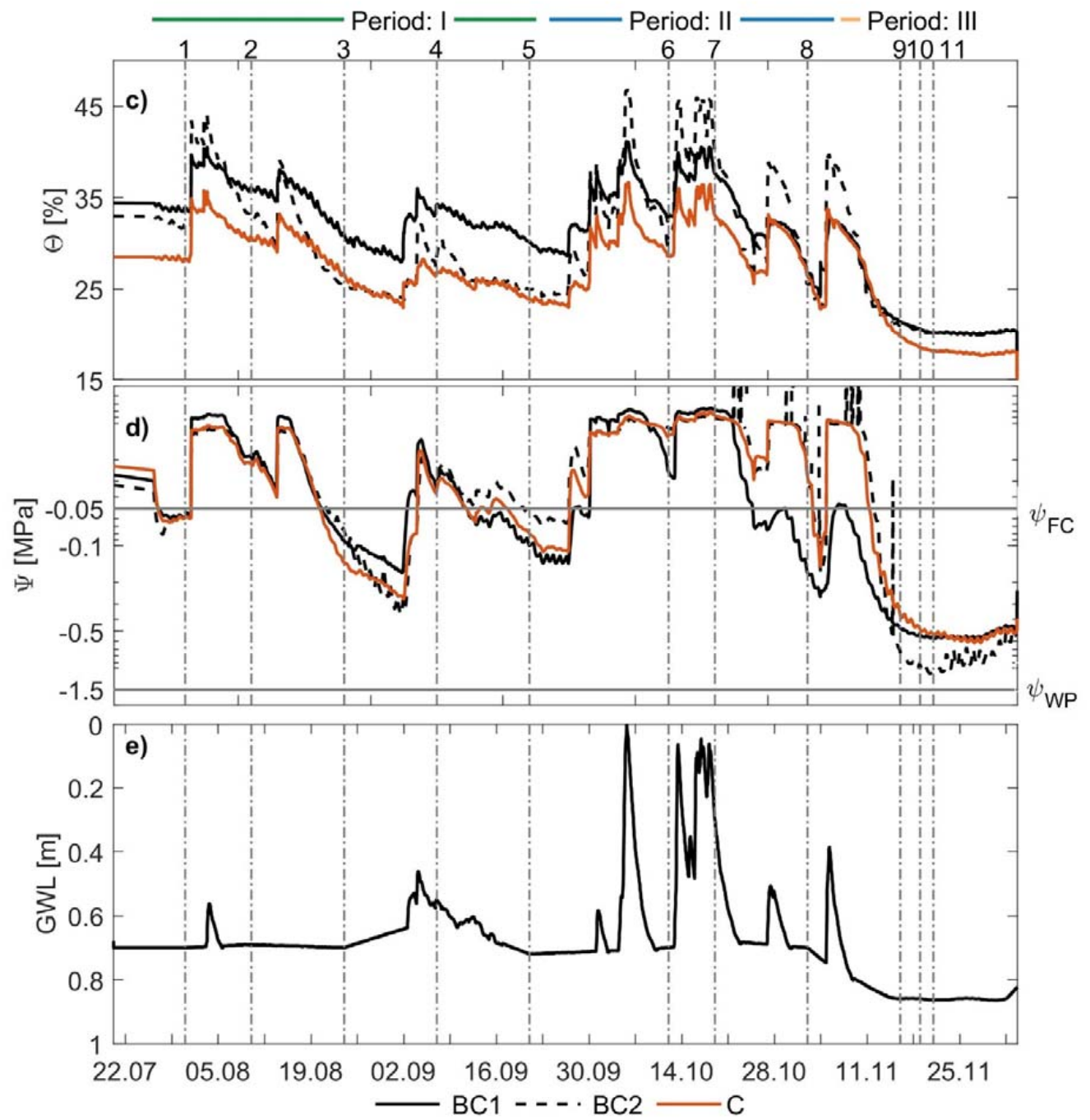

Figure 3 (continued) Time series of: (c) average volumetric water content and (d) the average water potential for each treatment; (e) measured groundwater level. The different water sampling days 1-11 are indicated in each panel as vertical dashed lines and numbered on top of panel $c$ and the date are given on the $x$-axis of panel $e$ as dd.mm. Period I, II and III are indicated on the top of panel c. 

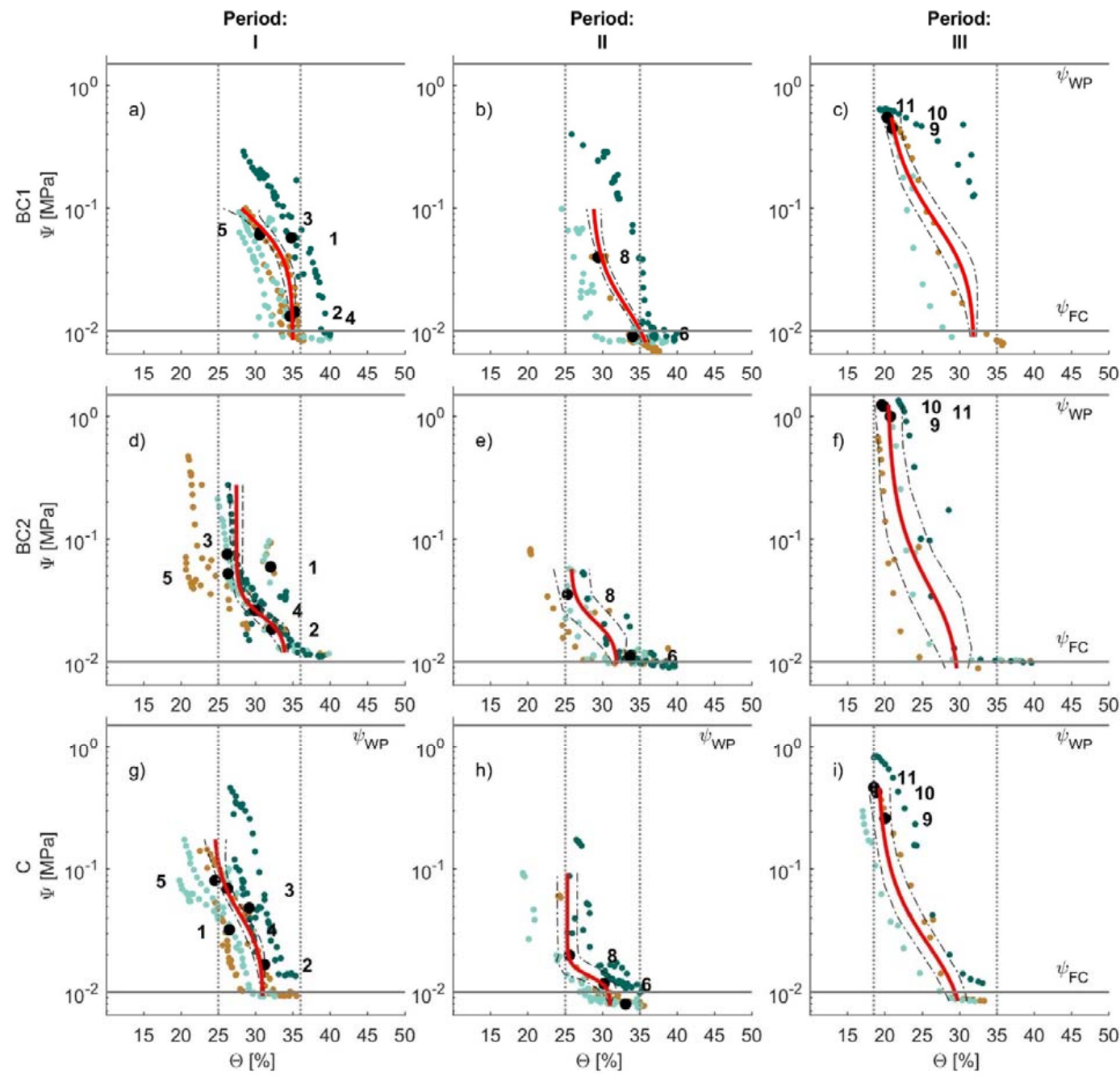

Figure 4 The soil matric potential represented as a function of average soil water content of the different plots (colors) for the treatments BC1 (a-c), BC2 (d-f) and C (g-i) and the Periods I, II and III (columns). The fitted average soil water retention curves within a treatment using equation 1 (red line) including the $95 \%$ confidence interval (dashed line). Black circles indicate the soil water content and soil matric potential on the sampling days indicated by numbers. 
https://doi.org/10.5194/hess-2020-404

Preprint. Discussion started: 20 August 2020

(c) Author(s) 2020. CC BY 4.0 License.
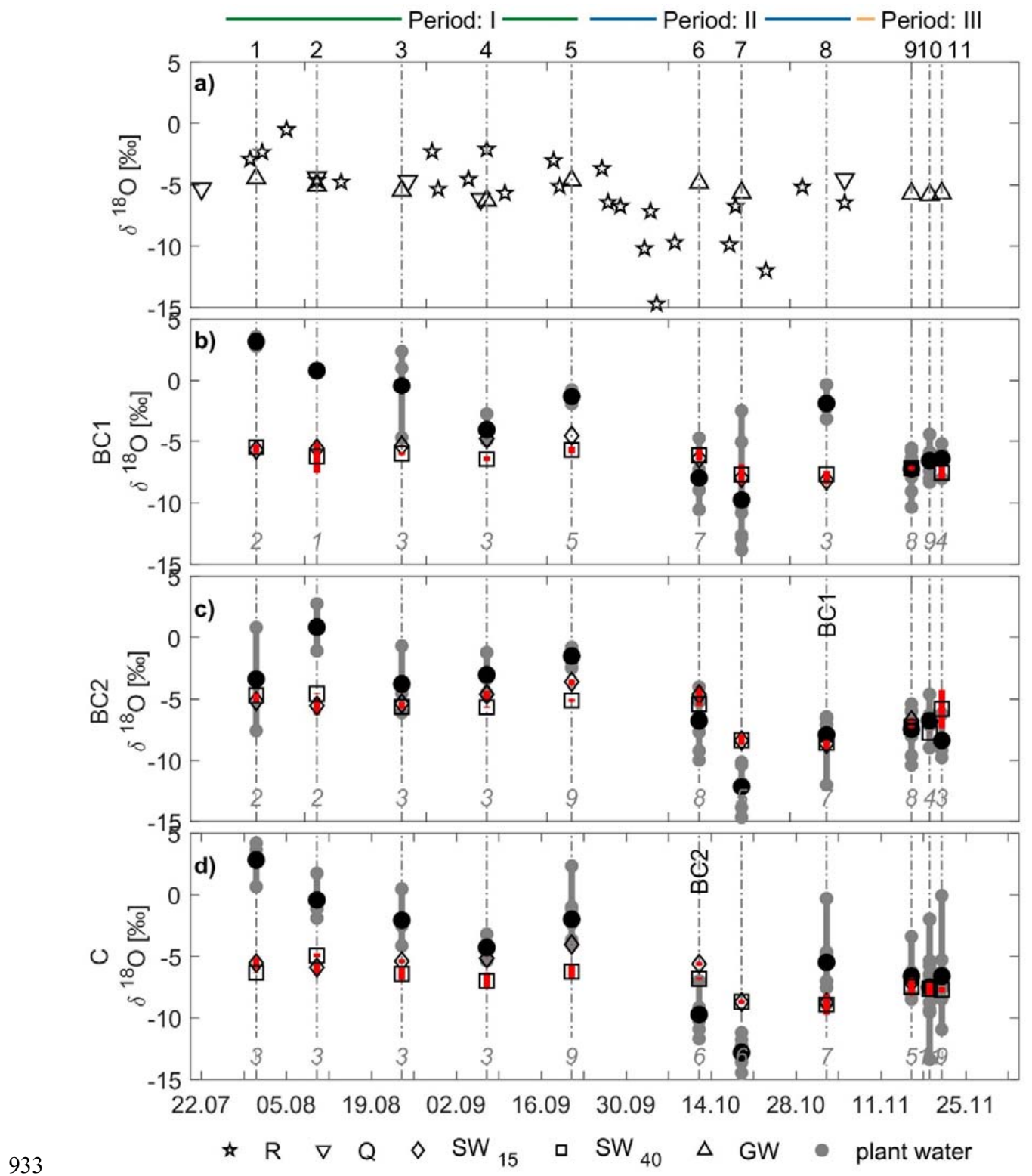

Figure 5 Time series of (a) $\delta^{18} O$ in rainfall, irrigation water, ground water and (b-d) soil water sampled at $15 \mathrm{~cm}\left(S W_{15}\right)$ and $40 \mathrm{~cm}\left(S W_{40}\right)$, ranges of $\delta^{18} \mathrm{O}$ of $S W$ (red line). The $\delta^{18} \mathrm{O}$ of plant water (grey circle) and its average (black circle) are shown for the BC1 (b), BC2 (c) and control treatment (d), for sampling days 1-11 (indicated in each panel as vertical dashed lines and numbered on top of panel a). Period I, II and III are indicated on the top of panel a. Italic numbers in panels b-d indicate the numbers of plants samples. Significant differences among the average plant water values (per treatment $n>3$ ) of each sampling day are on the vertical dashed lines as letter of the treatment e.g. BC1, BC2 or C (Tukey's honestly significant difference criterion $\alpha=0.05$ ). 
https://doi.org/10.5194/hess-2020-404

Preprint. Discussion started: 20 August 2020

(c) Author(s) 2020. CC BY 4.0 License.
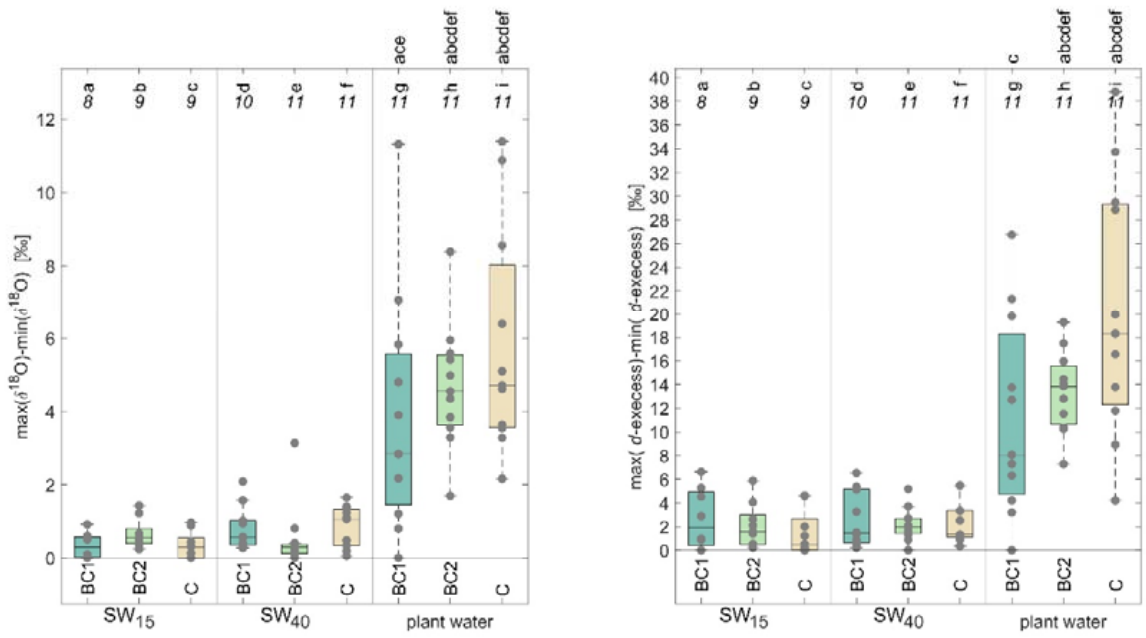

94

Figure 6 The variability in stable isotope composition $\delta^{18} \mathrm{O}$ (left) and d-excess (right) expressed as range (maximumminimum observed isotopic composition) for the soil water collected at $15 \mathrm{~cm}\left(S W_{15}\right)$ and $40 \mathrm{~cm}\left(S W_{40}\right)$ below surface, and plant water in the BC1, BC2 and control treatment. The boxes show the range of values for different sample groups (showing the median and the interquartile range, with whiskers indicating $10^{\text {th }}$ and $90^{\text {th }}$ percentiles). Circles indicate the data points. Numbers above each box indicate the number of samples available. Letters on top of each box indicate significant differences among the average values of the different groups (Tukey's honestly significant difference criterion $\alpha=0.05$ ). 
https://doi.org/10.5194/hess-2020-404

Preprint. Discussion started: 20 August 2020

(c) Author(s) 2020. CC BY 4.0 License.
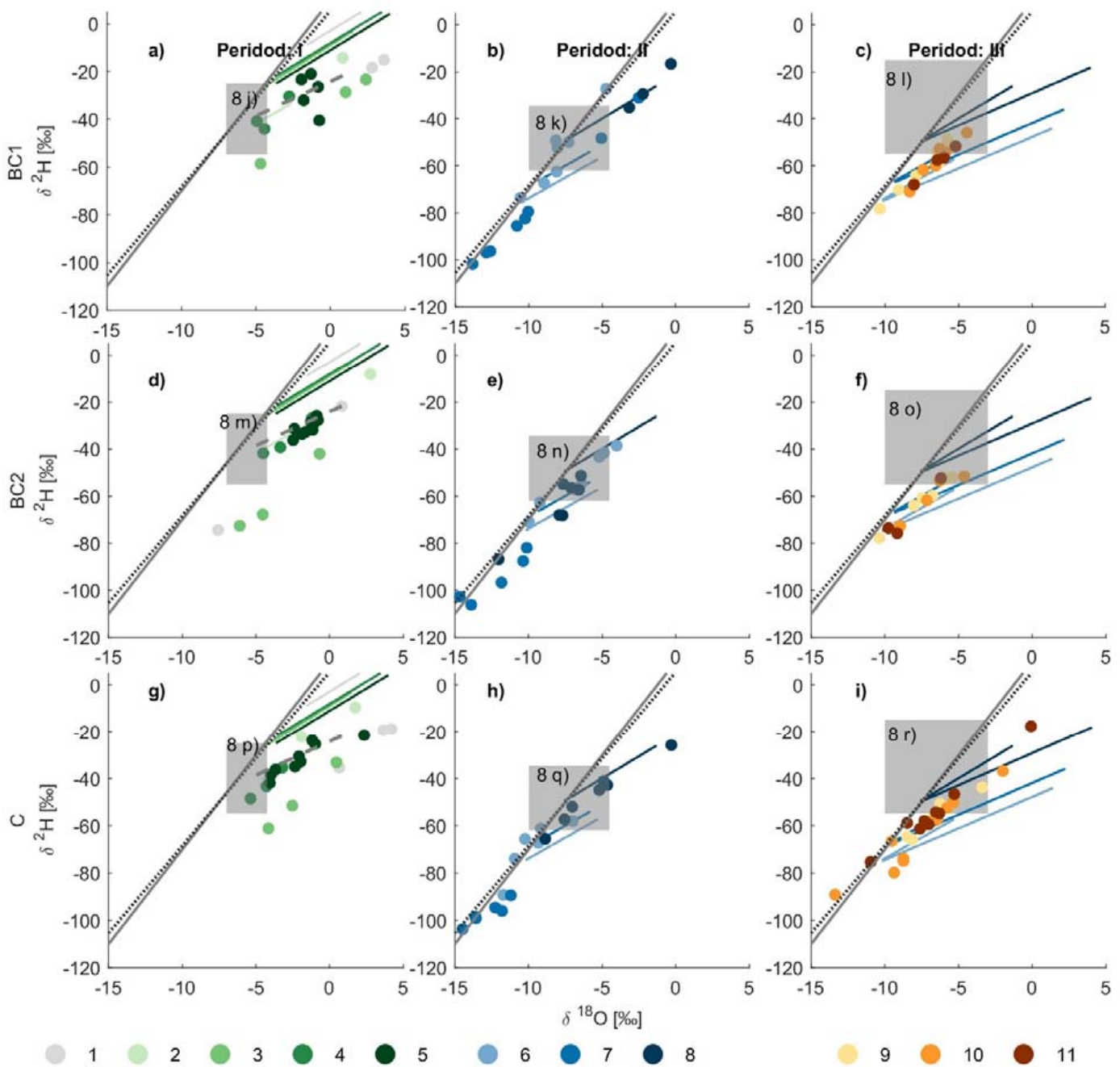

Figure 7 The dual isotope space with the isotopic composition of plant water samples (circles), the calculated evaporation lines of residual rainfall and sampled soil water for the treatments $B C 1(a-c), B C 2(d-f)$ and $C(g-i)$ and periods I-III (columns). Colors indicate the different sampling days (note that lines in period III are blue because they have been obtained from samples taken in period II). The local meteoric line (black dotted line) and global meteoric water line (grey solid line) are indicated in all panels. The grey dashed lines (panel a, $d$ and $g$ ) indicate the evaporation line of median soil water. Isotopic compositions of irrigation, soil water and groundwater vary within the grey shaded squares indicated as $8 j-8 r$, and enlarged in figure $8 j$-r. 
https://doi.org/10.5194/hess-2020-404

Preprint. Discussion started: 20 August 2020

(c) Author(s) 2020. CC BY 4.0 License.
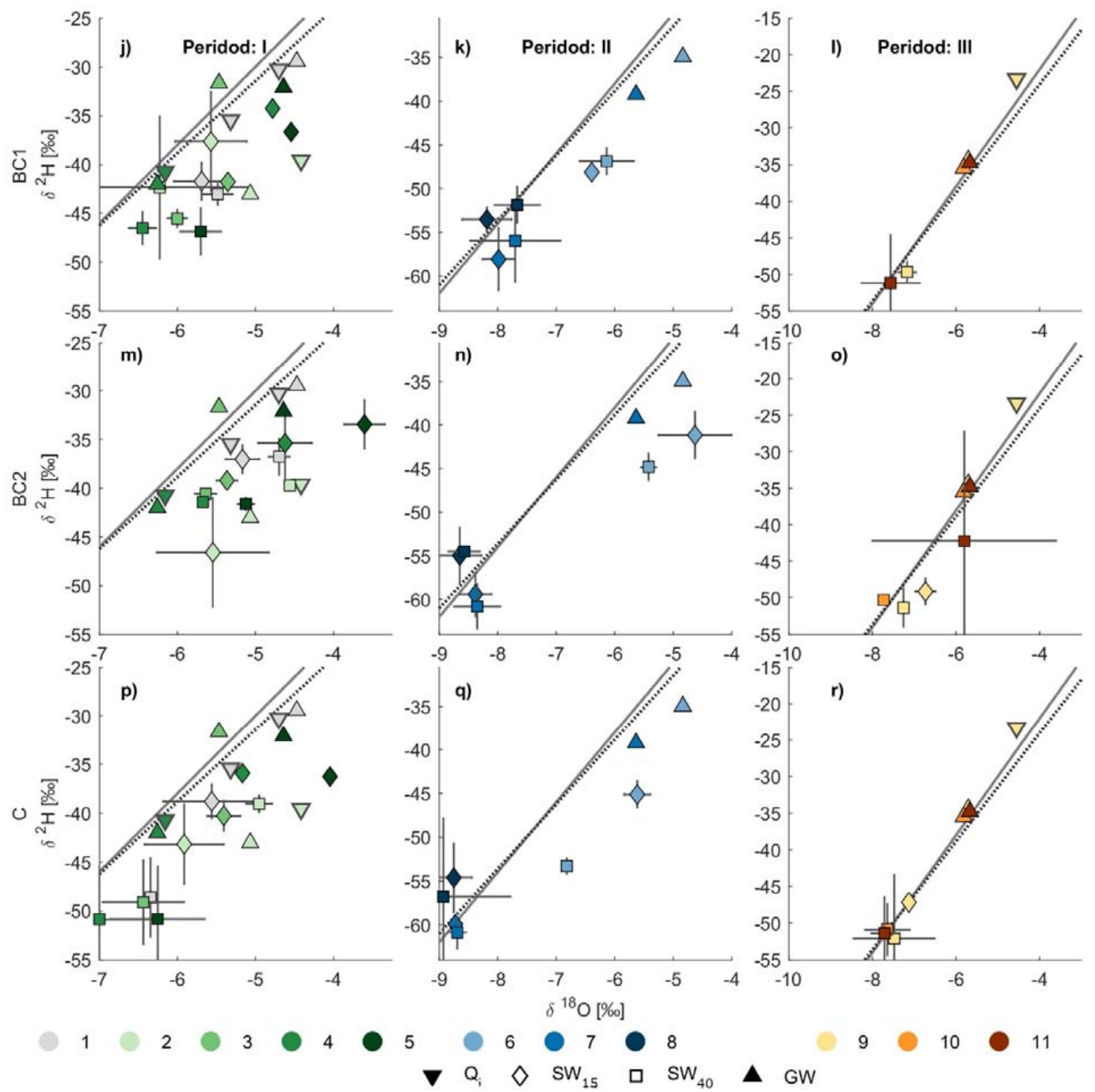

GW

Figure 8 The dual isotope space with the isotopic composition of irrigation (down facing triangle), soil water collected at $15 \mathrm{~cm}\left(S W_{15}\right.$, diamond) and $40 \mathrm{~cm}\left(S W_{40}\right.$, square) and groundwater (upward facing triangle). The local meteoric line (black dotted line) and global meteoric water line (grey solid line) are indicated in all panels. The different treatments BC1 (j-l), BC2 (m-o) and C (p-r) and different periods I-III (columns) indicated in grey panels of Figure 7 a-i. Colors indicate the different sampling days. 
964 Appendix

965 Table A1 Soil characteristics of the experimental site.

\begin{tabular}{r|c|c|c}
\hline & BC1 & BC2 & C \\
\hline Soil $(0-20 \mathrm{~cm})$ texture & \multicolumn{3}{|c}{$34 / 30 / 36$} \\
sand/silt/clay & \multicolumn{3}{|c|}{} \\
\hline Infiltration capacity & $15 / 30$ & $15 / 40$ & $8 / 40$ \\
Wet / Dry season & & & \\
{$\left[\mathrm{mm} \mathrm{h}^{-1}\right]$} & & & \\
\hline
\end{tabular}

\begin{tabular}{|c|c|c|c|}
\hline $\mathrm{pH}$ & 6.5 & 6.3 & 6.4 \\
\hline $\mathrm{Ca}[\mathrm{mol} \mathrm{kg}-1]$ & 11.77 & 12.43 & 11.77 \\
\hline $\mathrm{Mg}\left[\mathrm{mol} \mathrm{kg}{ }^{-1}\right]$ & 2.60 & 2.63 & 2.47 \\
\hline $\mathrm{K}\left[\mathrm{mol} \mathrm{kg}{ }^{-1}\right]$ & 0.87 & 0.97 & 0.80 \\
\hline $\mathrm{P}\left[\mathrm{mg} \mathrm{L}^{-1}\right]$ & 22.3 & 29.0 & 21.6 \\
\hline $\mathrm{Zn}\left[\mathrm{mg} \mathrm{L}^{-1}\right]$ & 3.2 & 3.3 & 3.1 \\
\hline $\mathrm{Mn}\left[\mathrm{mg} \mathrm{L}^{-1}\right]$ & 24.0 & 30.6 & 22.0 \\
\hline $\mathrm{Cu}\left[\mathrm{mg} \mathrm{L}^{-1}\right]$ & 9.3 & 11.0 & 9.6 \\
\hline $\mathrm{Fe}\left[\mathrm{mg} \mathrm{L}^{-1}\right]$ & 43.00 & 57.33 & 45.00 \\
\hline Organic C $[\%]$ & 2.29 & 2.18 & 2.16 \\
\hline Total N [\%] & & 0.15 & \\
\hline
\end{tabular}


https://doi.org/10.5194/hess-2020-404

Hydrology and

Preprint. Discussion started: 20 August 2020

(c) Author(s) 2020. CC BY 4.0 License.

968 Table $A 2$ The fitted parameters $\theta_{\mathrm{r},} \boldsymbol{\alpha}$ and $n$ the average soil water retention curves of the different treatments $(B C 1, B C 2$ 969 and C) and the Periods I-III of equation 1 with the 95\% confidence interval in brackets.

\begin{tabular}{|c|c|c|c|c|c|c|c|c|c|}
\hline & \multicolumn{3}{|c|}{$\mathrm{BC} 1$} & \multicolumn{3}{|c|}{$\mathrm{BC} 2$} & \multicolumn{3}{|c|}{$\mathrm{C}$} \\
\hline & \multicolumn{3}{|c|}{ Period } & \multicolumn{3}{|c|}{ Period } & \multicolumn{3}{|c|}{ Period } \\
\hline & $\mathrm{I}$ & II & III & I & II & III & I & II & III \\
\hline$\theta_{r}$ & $\begin{array}{c}0.2 \\
(-0.2,0.6)\end{array}$ & $\begin{array}{c}0.3 \\
(0.3,0.3)\end{array}$ & $\begin{array}{c}0.2 \\
(0.2,0.2)\end{array}$ & $\begin{array}{c}0.3 \\
(0.3,0.3)\end{array}$ & $\begin{array}{c}0.3 \\
(0.2,0.3)\end{array}$ & $\begin{array}{c}0.2 \\
(0.2,0.2)\end{array}$ & $\begin{array}{c}0.2 \\
(0.2,0.3)\end{array}$ & $\begin{array}{c}0.3 \\
(0.2,0.3)\end{array}$ & $\begin{array}{c}0.2 \\
(0.2,0.2)\end{array}$ \\
\hline$\alpha$ & $\begin{array}{c}13 \\
(-6.7,33)\end{array}$ & $\begin{array}{c}78 \\
(65,90)\end{array}$ & $\begin{array}{c}18 \\
(8.1,29)\end{array}$ & $\begin{array}{c}44 \\
(36,52)\end{array}$ & $\begin{array}{c}49 \\
(29,70)\end{array}$ & $\begin{array}{c}34 \\
(-14,81)\end{array}$ & $\begin{array}{c}27 \\
(20,34)\end{array}$ & $\begin{array}{c}75 \\
(61,88)\end{array}$ & $\begin{array}{c}58 \\
(30,85)\end{array}$ \\
\hline$n$ & $\begin{array}{c}2.5 \\
(-0.3,5.4)\end{array}$ & $\begin{array}{c}2.6 \\
(1.8,3.4)\end{array}$ & $\begin{array}{c}2 \\
(0.9,3.1)\end{array}$ & $\begin{array}{c}5.7 \\
(1.4,10)\end{array}$ & $\begin{array}{c}5.1 \\
(-0.2,12)\end{array}$ & $\begin{array}{c}2 \\
(0.2,3.8)\end{array}$ & $\begin{array}{c}3 \\
(1.2,4.8)\end{array}$ & $\begin{array}{c}10 \\
(-0.4,24)\end{array}$ & $\begin{array}{c}2 \\
(1.2,2.9)\end{array}$ \\
\hline
\end{tabular}

970 
https://doi.org/10.5194/hess-2020-404

Preprint. Discussion started: 20 August 2020

(c) Author(s) 2020. CC BY 4.0 License.
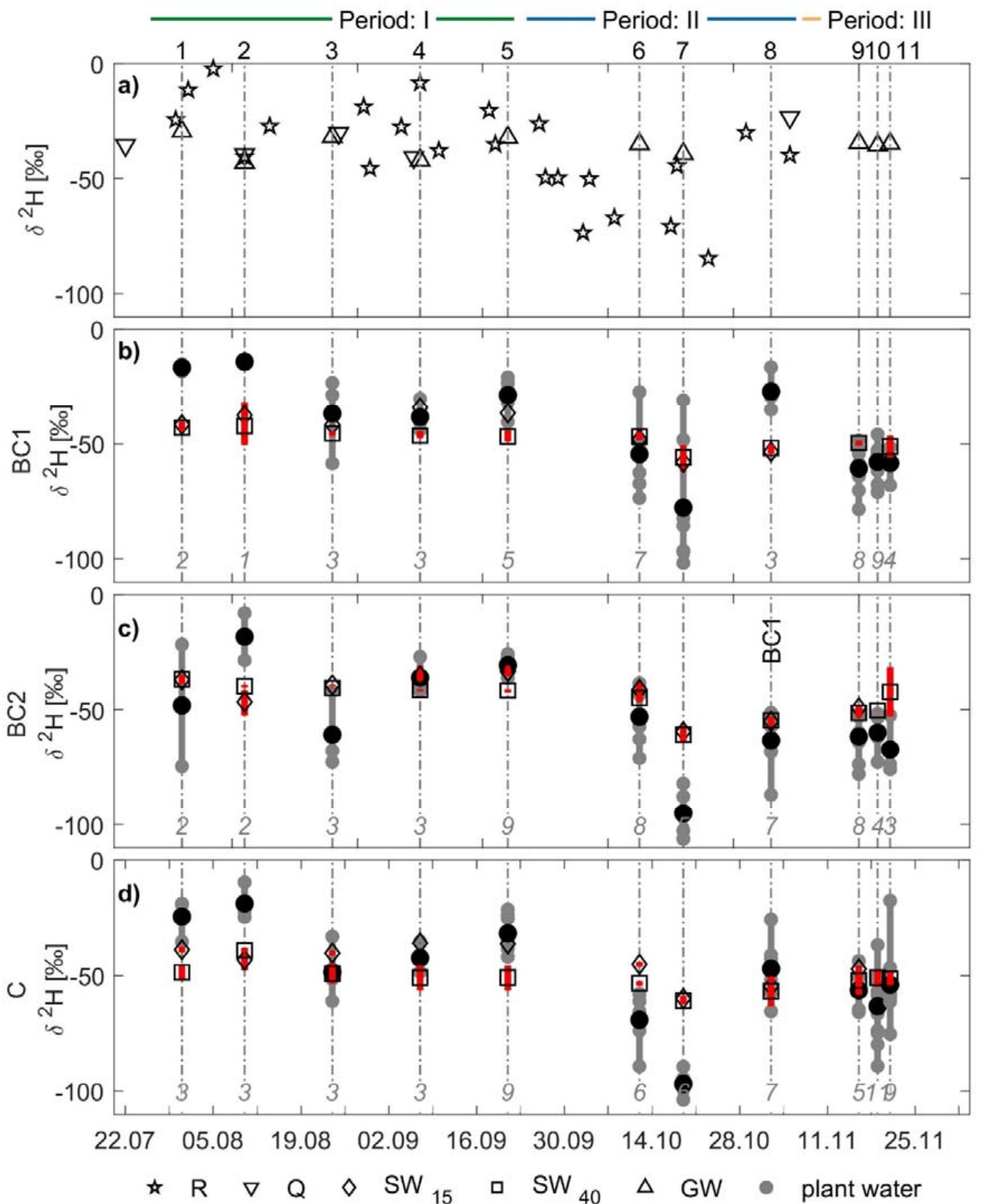

Figure A1 Time series of (a) $\delta^{2} \mathrm{H}$ in rainfall, irrigation water, ground water and (b-d) soil water sampled at $15 \mathrm{~cm}(\mathrm{SW15})$ and $40 \mathrm{~cm}(\mathrm{SW} 40)$, ranges of $\delta^{2} \mathrm{H}$ of $S W$ (red line). The $\delta^{2} \mathrm{H}$ of plant water (grey circle) and its average (black circle) are shown for the BC1 (b), BC2 (c) and control treatment (d), for sampling days 1-11 (indicated in each panel as vertical dashed lines and numbered on top of panel a). Periods I, II and III are indicated on the top of panel a. Italic numbers in panels b-d indicate the numbers of plants samples. Significant differences among the average plant water values (per treatment $n>3$ ) of each sampling day are on the vertical dashed lines as letter of the treatment e.g. BC1, BC2 or C (Tukey's honestly significant difference criterion $\alpha=0.05$ ). 
https://doi.org/10.5194/hess-2020-404

Preprint. Discussion started: 20 August 2020

(c) Author(s) 2020. CC BY 4.0 License.
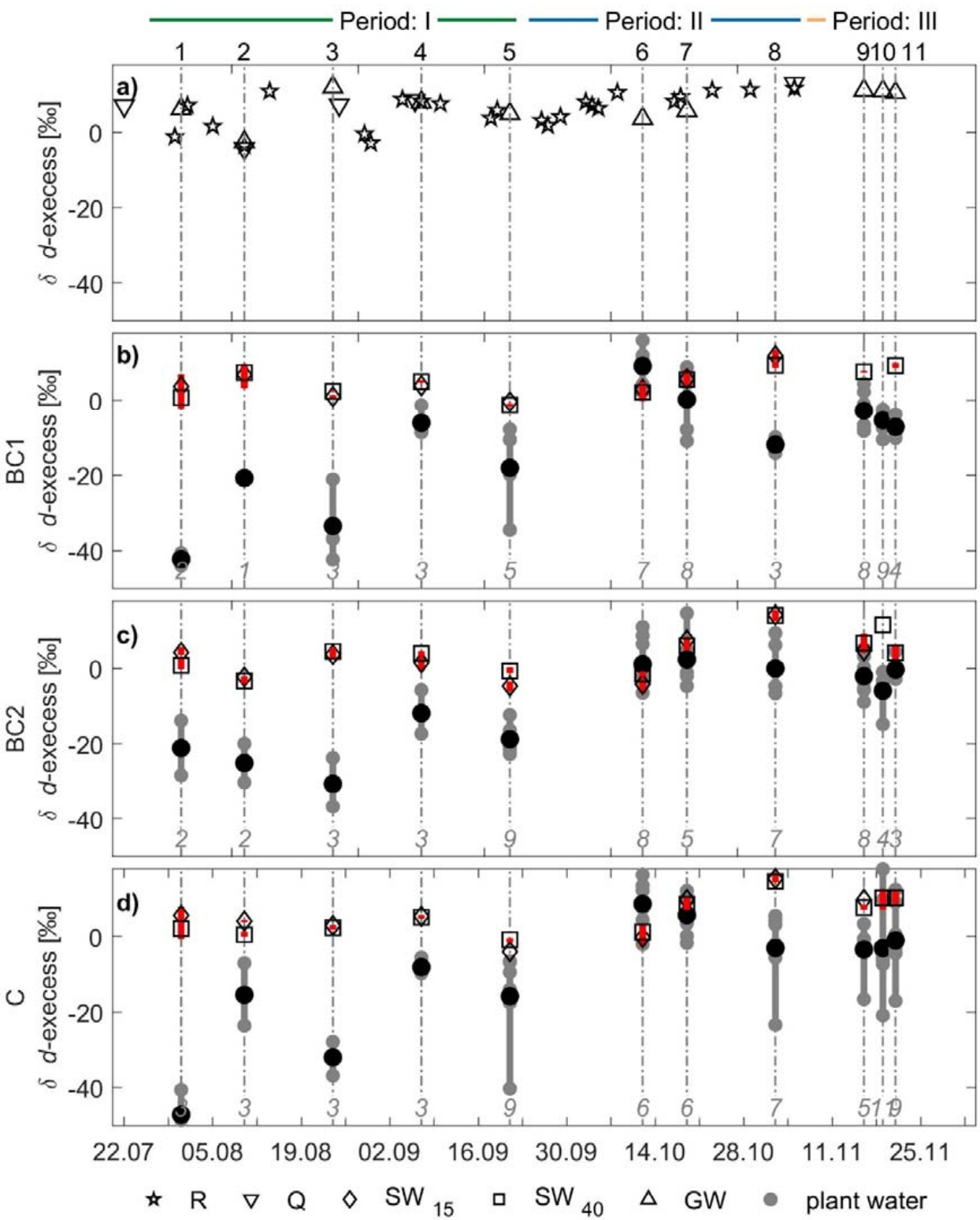

Figure A2 Time series of (a) d-excess in rainfall, irrigation water, ground water and (b-d) soil water sampled at $15 \mathrm{~cm}$ $\left(S W_{15}\right)$ and $40 \mathrm{~cm}\left(S W_{40}\right)$, ranges of d-excess of $S W$ (red line). The d-excess of plant water (grey circle) and its average (black circle) are shown for the BC1 (b), BC2 (c) and control treatment (d), for sampling days 1-11 (indicated in each panel as vertical dashed lines and numbered on top of panel a). Periods I, II and III are indicated on the top of panel a. Italic numbers in panels b-d indicate the numbers of plants samples. Significant differences among the average plant water values (per treatment $n>3$ ) of each sampling day are on the vertical dashed lines as letter of the treatment e.g. BC1, BC2 or C (Tukey's honestly significant difference criterion $\alpha=$ 0.05). The d-excess was defined as d-excess $=\delta^{2} H-8 \cdot \delta^{18} O$ (Dansgaard, 1964) using data from Figure 5 and A1. 
https://doi.org/10.5194/hess-2020-404

Preprint. Discussion started: 20 August 2020

(c) Author(s) 2020. CC BY 4.0 License.
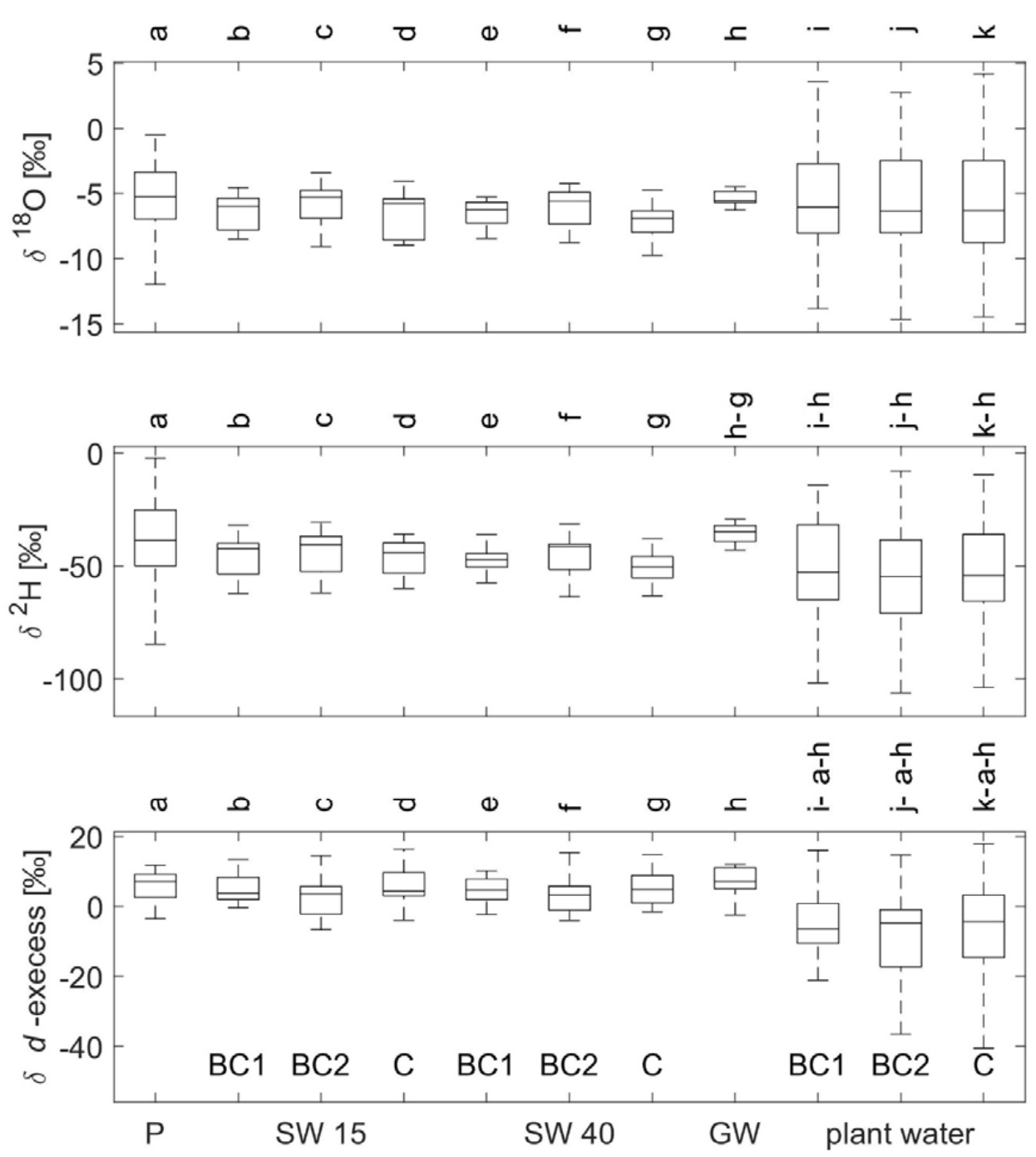

Figure $A 3$ The variability in stable isotope composition $\delta^{18} \mathrm{O}, \delta^{2} \mathrm{H}$ and d-excess. The $x$-axis indicates the sampled precipitation, soil water collected at $15 \mathrm{~cm}\left(S W_{15}\right)$ and $40 \mathrm{~cm}\left(S W_{40}\right)$ below surface, groundwater and plant water where $B C 1, B C 2$ and $C$ indicate the three different treatments. The boxes show the range of values for different sample groups (showing the median and the interquartile range, with whiskers indicating 10th and 90th percentiles). Letters on top of each box indicate significant differences among the average values of the different groups (Tukey's honestly significant difference criterion $\alpha=0.05$ ). 